\title{
4. 新設，改修高炉および附属設備
}

第7 回より第18回の製銑部会にいたる時期においては 経済の高度成長にともない, 鉄鋼業の設備拡張はいちぢ るしいものがあつた。製銑設備も飛躍的な伸長を見せ， 高炉の大型化, フリースタンディング型あるいは鉄柱鉄 皮式の出現, 原料装入設備関係の自動制御化, 熱風炉の 大型化また熱風炉切替および然焼制御の自動化また電気 収䈃器の大幅な採用などの技術的な発展とともに, 送風 設備に見られるよ5に, 従来のターボ：ブロワーから軸 流式ブロワーの新規採用など, 設備の合理化も盛んに行 なわれてきた。この期間における新設高炉基数は14基, 改修高炉基数は13基に達し，銑鉄生産能力は基準能力を 取り上げても, 新設高炬では年間能力約 600 万 $\mathrm{t}$, 改修 高炉では年間能力約 430 万 $\mathrm{t}$ (昭和37年上期現在) でわ が国総出銑量に占める割合はそれぞれ，約 $37 \%$ および約 27\%に達している.しかし昭和36年下期より国際収支の 赤字による大幅な金融引締めの結果, 設備投資の削減,

景気の沈滞など経済基調の変化を受け、鉄鋼界も真向か ら不況の波をかぶり，新設設備の繰り延べ，または中止 などが行なわれ，その後の設備の伸長は鈍つている. 製 銑部会において発表された新設および改修高炉を第 7 回 より第18回までまとめると表4・1のよ5になる.

$4 \cdot 1$ 高炉本体および配置

高炬々体の型式については, 従来の鉄带式あるいは鉄 皮式より脱してフリースタンディング型鉄皮式が大幅に
採用され，新設および改修高炉の約半数を占めるにいた つた，一方大型高炉に対しては，わが国独自の鉄柱鉄皮 式が採用され従来の鉄皮式は改修高炣に多く見られるが 䄪 $1 / 4$ で鉄帯式の烼はわずか 1 基しか見当らない.炬命延 長の対策としても種々の改善がなされ耐火煉瓦について は, 炉底湯溜部にカーボン煉瓦が大幅に採用され, 朝顔 部にかけてもその使用が試みられてきた。 また炉体の泠 却も強化され特に炉胸部にはほとんどの炉が全体にわた つて銅製または鋳鉄製の冷却板を採用している。

\section{$4 \cdot 1 \cdot 1$ 溶鉱炉のプロフィル}

溶鉱炉のプロフィルは吹製銑種, 装入原料の物理的, 化学的珄質ならびに操業方法によつて左右される. また 溶鉱灯の出銑能力は炬床径および炉内容積によつて大き く影響を受ける. 過去における高炬のプロフィルの変遷 を米国に打ける U.S. Steel Corp. の高炉を例にとつて みると、19世紀後半では炉休径が小さい割合に朝顔部の 高さが大きく, 朝顔角度は比較的浅かつたが, 20世紀に 入り炉高扣よび帄床径が徐々に大きくなり, 朝顔部の高 さは明らかに低くなつてきた. その後, 朝顔角度も急傾 斜となり炉腹径を余り大きくせずに炉床径を大きくして いる. 最近にいたり炬床径が $8 \mathrm{~m}$ 以上になるにおよんで 朝顔部の高さは低くなり急傾斜の角度を持ち, 炉腹径が いちぢるしく增大している.わが国に打ける高炉のプロ フィルも高炉操業技術, 原料処理方法の発達に伴いほぼ

表 $4 \cdot 1$ 新設および改修高帄一覧表

\begin{tabular}{|c|c|c|c|c|c|c|c|c|c|c|c|c|c|c|c|c|c|}
\hline \multirow{2}{*}{$\frac{\text { No. }}{1}$} & \multicolumn{2}{|l|}{ 高 } & 帄 & & \multicolumn{2}{|c|}{$\begin{array}{l}\text { 新設又は } \\
\text { 改修の別 }\end{array}$} & \multirow{2}{*}{\begin{tabular}{|c|}
$\begin{array}{c}\text { 公称能力 } \\
(\mathrm{t} / \mathrm{d})\end{array}$ \\
1,300
\end{tabular}} & \multirow{2}{*}{$\frac{\begin{array}{c}\text { 炬内容程 } \\
\left(\mathrm{m}^{3}\right)\end{array}}{1,273}$} & \multirow{2}{*}{$\frac{\text { No. }}{15}$} & \multicolumn{2}{|l|}{ 高 } & 炉 & 名 & \multicolumn{2}{|c|}{$\begin{array}{l}\text { 新設又は } \\
\text { 改修の別 }\end{array}$} & \multirow{2}{*}{$\begin{array}{c}\begin{array}{c}\text { 公称能力 } \\
(\mathrm{t} / \mathrm{d})\end{array} \\
1,500\end{array}$} & \multirow{2}{*}{$\frac{\begin{array}{c}\text { 姪内容䅡 } \\
\left(\mathrm{m}^{3}\right)\end{array}}{1,515}$} \\
\hline & 富士 & 広 & 畑 & 第 1 高炉 & 改 & 修 & & & & 富士 & 広 & 畑 & 第 3 高炉 & 新 & 設 & & \\
\hline 2 & 富士 & 窒 & 留 & 第 2 高师 & 改 & 修 & 1,000 & 1,042 & 16 & 失 & 尼 & 崎 & 第 1 高炉 & 改 & 修 & 500 & 662 \\
\hline 3 & 住 & 小 & 倉 & 第 2 高 & 改 & 修 & 6 & 752 & 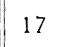 & & 西 & 島 & 第 1 高炉 & 新 & & . & 326 \\
\hline 4 & 尼鉄 & 尼 & 崎 & 第 2 高 & 新 & 設 & & 753 & 18 & & & 崎 & 第 5 高炉 & $4 x$ & 㘹 & 600 & 903 \\
\hline 5 & 川鉄 & 千 & 葉 & 第 2 高 & 新 & 設 & 1,0 & 1,1 & & 管 & 鶴 & 見 & 第 1 & 改 & 修 & & 143 \\
\hline 6 & 富士 & 㵚 & 石 & 1 高 & 改 & 修 & 00 & 018 & 20 & : & & 蘭 & 第 47 & 新 & 設 & & 701 \\
\hline 7 & 神鋼 & 神 & 戸 & 第 1 高 & 新 & 設 & 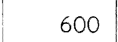 & 753 & 21 & & & 歌山 & $\vec{p}$ & 所 & 設 & 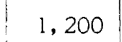 & 350 \\
\hline 8 & 八幡 & 戸 & 畑 & 第 & 新 & 設 & 1,5 & 1,603 & 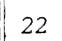 & & 司 & 岡 & 与 & P & & & 279 \\
\hline 9 & 鋼管 & 川 & 崎 & 第 2 高炉 & 新 & 設 & 1,000 & 1,137 & 23 & 川鉄 & 1 & 葉 & 第 4 高炉 & 新 & & 1,500 & 1,689 \\
\hline 10 & 中山 & 船 & 町 & 第 2 高炉 & 改 & 修 & 550 & 698 & 24 & 富士 & 鉒 & 石 & 第 2 高炉 & 改 & 修 & 1,600 & 1,610 \\
\hline 11 & 鋼管 & 川 & 崎 & 第 3 高炉 & 改 & 修 & 600 & 965 & 25 & 神鋼 & 神 & 戸 & 第 2 高炉 & 新 & 設 & 1,000 & 1,243 \\
\hline 12 & 川鉄 & 千 & 葉 & 第 3 高炉 & 新 & 設 & 1,500 & $1,689^{\circ}$ & 26 & 八幡 & 戸 & 畑 & 第 3 高炉 & 新 & 設 & 1,900 & 1,947 \\
\hline 13 & 富士 & 室 & 蘭 & 第 1 高炉 & 改 & 修 & 1,000 & 1,042 & 27 & 川鉄 & & 葉 & 第 1 高炬 & 改 & & 900 & 913 \\
\hline 14 & 八幡 & 戸 & 畑 & 第 2 高炉 & 新 & 設 & 1,500 & 1,657 & & & & & & & & & \\
\hline
\end{tabular}




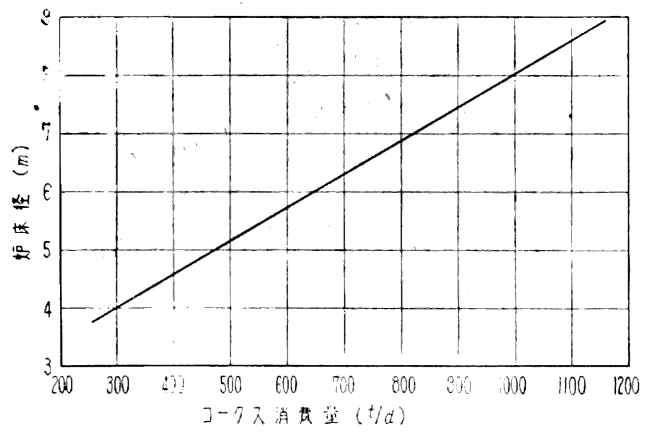

图 4・1高炬のコークス消費量と炉床径との関係 (O.R. RICE)

同じうな傾向をたどつてきている.

新しい高炉を建設する場合, 炬の生産能力の標準とな るものはコークスの然㸁率であるといらことは G.HEYNERT, O.R. RICE らが言明しており，O.R. RICE は, 高 炬の炉本径と 1 日当りのコークス消費量との関係を四 4 . 1のように示している, ここでュークスの然焼は, 羽口 先 $6 \mathrm{ft}$ 幅の環状帯に限定されると考えており, 環状带の 面積は灯床径に比例するので, 眓のような関保が出てく る. O.R. RICE は，この環状帯 $1 \mathrm{~m}^{2}$ 当たり1日のコ ークス燃焼量を実績から $30 \mathrm{t} 753$ と推定している.

炬床径を基準にして種々の炬のプロフィルの算定を行 ならことができるが，O.R. RICE は炬口面積は炉休環状 面䆅とほぼ同じであるべきだと提案しているわかが国に 拈ける代表的大型昵についてこれらの関倸を図 $4 \cdot 2$ に示 めす。四中の曲線は炬口面積と炬休環状面積とが等しい 関係を表わしている.

な扰高炉のプロフィル形式については, M. A. PavLoff および A.N. RAMM が炉高, 炉床径, 炬腹径掞よび炬口 径と, 実効内容積 (羽口面とストックラインの間の内容

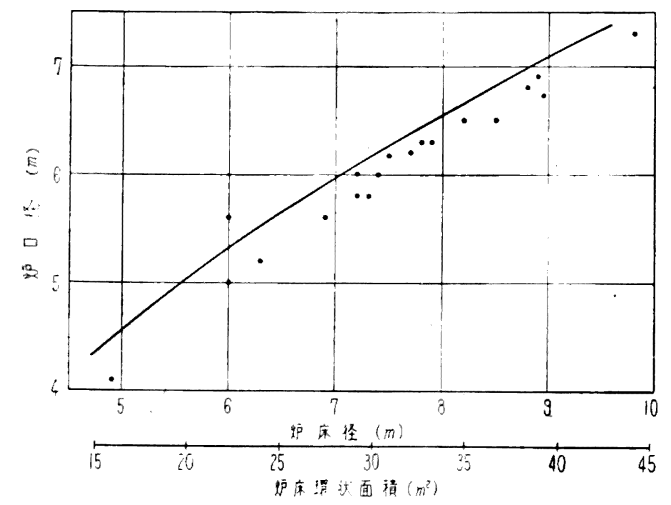

図 $4 \cdot 2$ わが国の代表的高炬の炬床径, 洰床環 状面程と帄口径との関倸

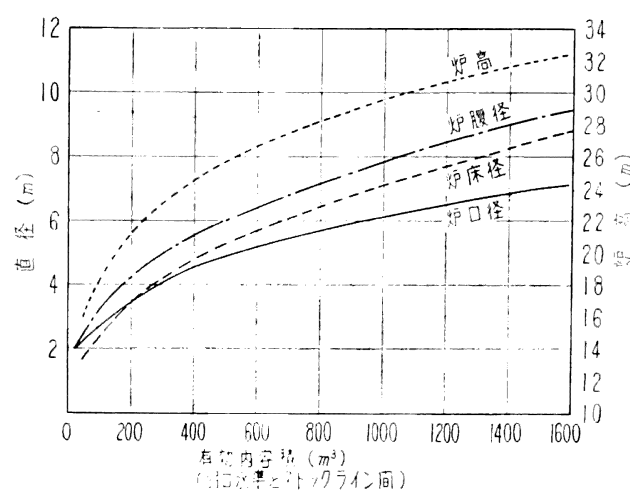

図 4 .3 高炬の有効内客程と各部寸法との関係 (M. A. PAVLOFF and A. N. Ramm)

積）との関係を図 4 ·3に示すよ5に表わしている。また 实効内容積と炣休面積との比で表わす方法もあり, わが 国では $22 \mathrm{~m}^{3} / \mathrm{m}^{2} \sim 24 \mathrm{~m}^{3} / \mathrm{m}^{2}$ となつており, 諸外国の例 に比べやや低い値を示している. (ソ連23 $\mathrm{m}^{3} / \mathrm{m}^{2} \sim 28 \mathrm{~m}^{3}$ $/ \mathrm{m}^{2}$ 米国 $\left.23 \mathrm{~m}^{3} / \mathrm{m}^{2} \sim 27 \mathrm{~m}^{3} / \mathrm{m}^{2}\right)$

(1) 炬术 径

炉床径は, 高炉の出銑能力を決定する上に重要な因子 となるものである.

O.R. RICE は, 次の式を示している.

$$
\begin{aligned}
\text { コークス標準消費量 } & =30 \cdot 753 \times 5 \cdot 749(\mathrm{D}-2 \cdot 13) \\
& =177(\mathrm{D}-2 \cdot 13)(\mathrm{t} \text {-コークス/d })
\end{aligned}
$$

たたし，D；炉床径 $(\mathrm{m})$.

この式には, 炉休環状面積が含まれており,この面程 は, 次のとおりである。

$$
\begin{aligned}
& \mathrm{F}=\pi \cdot \delta 2 \mathrm{~S} \quad \text { ここで } \mathrm{S}=\mathrm{D} / 2-\delta / 2-\mathrm{f} \\
& \text { ゆえに } \mathrm{F}=\pi \cdot \delta(\mathrm{D}-\delta-2 \mathrm{f}) \\
& \text { たたし } \mathrm{D}: \text { 炉休径 }(\mathrm{m}) \\
& \mathrm{F}: \text { 炉床環状面積 }\left(\mathrm{m}^{2}\right) \\
& \delta: \text { 環状带の幅 }(\mathrm{m}) \\
& \mathrm{f}: \text { 羽口突出長さ }(\mathrm{m}) \\
& \text { この式に } \delta=1.83 \mathrm{~m}(6 \mathrm{ft}) \text { とし } \mathrm{f}=0.15 \mathrm{~m} \text { とすると, } \\
& \mathrm{F}=5,749(\mathrm{D}-2 \cdot 13) \mathrm{m}^{2}
\end{aligned}
$$

となる・

この式にわが国の主要高炉の灯林径の值を抑入して, 1 日当りのコークス消費量を算出してみると, 炣林径 8 m以上の炬については, 実際值で約10\%高い值を示して いる.それ以下の恼については, 近に实際値が低くなつ ている.この場合, 重油などの燃料吹き込みの影響は除 いて考慮されている.

また M.A. PavlofF の式によれば

$$
\mathrm{D}=\sqrt{4 \mathrm{C} / \pi \mathrm{R}}
$$


ただし D : 㠴休径 $(\mathrm{m})$

c：1日当りのコークス消費量 $(t / d)$

$\mathrm{R}$ ：1 日, 炉床面積 $1 \mathrm{~m}^{2}$ 当り, 燃烧する コークス消費量 $(\mathrm{t} / \mathrm{d})$

式中の R值を，わが国の大型高炉 $(1,000 \mathrm{t} / \mathrm{d}$ 以上)に 求めてみると, 䄪 $20 \mathrm{t} / \mathrm{d} / \mathrm{m}^{2}$ の高い值を示めし、それ以 下の中型炉では䄪 $17 \mathrm{t} / \mathrm{d} / \mathrm{m}^{2}$ の值を示している.

湯溜高さは, 1 回の出銑量および鉱涬の一部を溜める に足りる容量が必要である. 米国においては, 1 回出銑 量の 3 倍の容䅡を取る例もある. わが国での最近の傾向 としては、この高さが大きくなりつつある.

(2) 炉高

高炬の出銑能力, 寸なわち炬容の増大にともない, 当 然, 炬高も高くなるが, 最近の傾向としては, 大型炬に なるに従い师容の増大に対し横方向の払がりが目立ち, 高さの增加割合はやや落ちている.

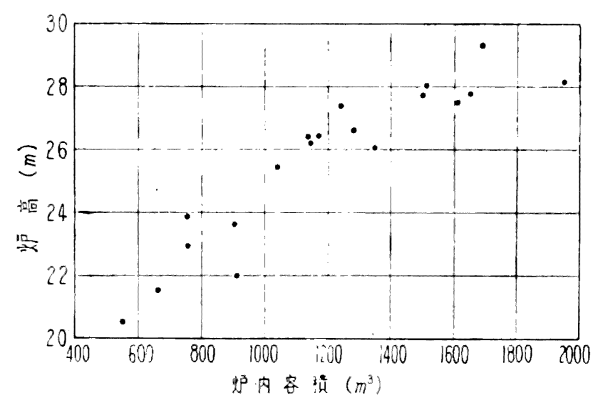

図 4.4 最近における代表的新設および改 修高炉の炉内容積と炬高との関係

图 4.4 に最近の代表的な新設および改修高炉の内容積 と高さとの関係を示す.

（3）朝顔部の高さならびに傾斜

内容積的 $600 \mathrm{~m}^{3}$ 以下の小型炉を除いて主要高炉の朝 顔部高さは $3.2 \mathrm{~m} \sim 3.5 \mathrm{~m}$ で炉高に対する比率は0.11〜 0.13の值を示し，低くなる傾向を示している．また朝顔 部の傾斜は急になりほとんどの炀が $81 〜 82^{\circ}$ でこの範用 外の炉は数少ない。これらのことは装入原料の管理が強 化され，炉の出銑能力の増大に伴い必然的にラピッドワ 一キングに適した焒型が採用された結果と思われる.

\section{（4）炬腹径および高さ}

最近の大型炉では炉腹径/炉休径の值は $1 \cdot 1$ 前後であ る.また炉高/炉腹径の值は約 $2 \cdot 8$ ～3.2 の間を示し, 諸 外国と同じ漸次低下の傾向を示している.すなわち高さ より横に払がる傾向がよく現われている.出銑能力 1,000 $\mathrm{t} / \mathrm{d}$ 以上の炬では炉腹部の高さは $2 \cdot 5 \sim 3 \cdot 0 \mathrm{~m}$ となつてい る.

\section{（5）炉口径および炉胸部高さ}

炉口径については O.R. RICE は炉口面観が前述の炉 本環状面積とほぼ同じであるような值をとるべきたと主 張している.わが国の代表的な大型炉では炉口面積は炉 朱環状面積より約 5〜10\%低い值を示しているが，この 傾向は米国およびソ連の大型炬の傾向とやや似ている. すなわち $1 \mathrm{~m}^{3}$ 当りの出銑能力の增大にもかかわらず最 近のコークス比の低下は著るしく炉頂ガス発生量もこれ と同じような傾向で減少している.炉胸部の高さは特に 装入物の粒度, コークスの強度などから炬内ガス流の分 布を充分考虑して決定されるべきであり，ガスが炉壁に 沿つて上年する場合, 煉瓦の摩耗が問題となる.したが つて炉胸内壁の傾斜角も同時に問題となる. 傾斜角は最 近の灿では䄪 $84 \sim 86^{\circ}$ とい5值をとつている.

高炬プロフィルの形状は下降して行く装入物と上升す るガスの向流動作が支障なく行なわれるよ5，現在まで の経験を基にして最も合理的な線で決めるべきであるこ とは論をまたない，特に近時燃料吹込み，酸素富化送風 などが再び注目され，また高圧操業も実際に採り入れら れてきている時, プロフィルに対する考察を一層深く進 めることは高炉の出銑効綮上萛にとつて重要である.

\section{$4 \cdot 1 \cdot 2$ 高炉の基礎}

高炉の基礎型式は建設地の地質状況（地耐力）によつ て決定されるが, 近時, 高炉の大型化, ならびに土木技 術の発達に伴なつて種々の工法が採用されてきている. 従来, ペデスタル式によるものが多かつたが, その後, ウエル工法が着目され, 最近の新設高炬の基礎には、こ れが大幅に採用されている. 大形鋼管ならびに形鋼の製 造技術が開発されるにつれ，これを利用した基礎型式と してベノート抗工法, H抗工法が採り入れられた. 最近 新設された高炉で，ペデスタル式による基礎型式として は尼鉄第 2 高炉, 大阪西島第 1 高炉などがあり, ウェル 工法では八幡戸畑第 1 高炉, 第 2 高炉, 川鉄千葉第 2 高 炬, 第 3 高炬, 第 4 高炉, などニューマチックケーソン 工法としては神鋼神戸第 1 高炉, 第 2 高炉, 住金和歌山 第1高炉などが举げられる.これらの工法の利害得失の 比較については, 立地条件, 経済性, 工期などから種々 問題があり明白な結論は出ていないよ5である.

新工法のベノート抗工法については, 富士鉒石第 2 高 炉の基礎を例にあげて説明すると, これは堀削管（ケー シングパイプ） 1 本の長さ $6 \mathrm{~m}$ 口径 $1 \mathrm{~m}$ のもの土中に 回転生入して，岩盤の中にパイプが喰込むまで土砂を外 部にくみ上げながら, 次から次へとパイプを接続して 


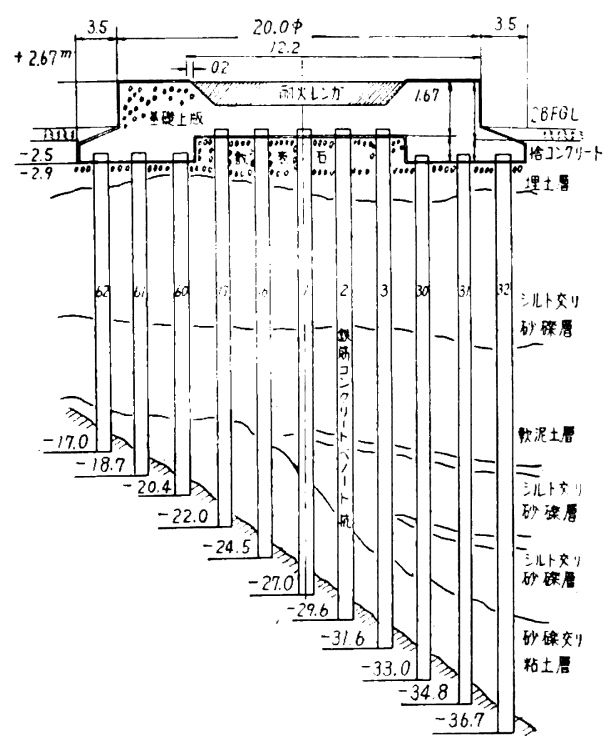

図 $4 \cdot 5$ ベノ一ト抗工法基礎断面威

所定の深さまで堀削し，その後鉄筇(上部のみ), 仯利, モルタルを注入し，パイプを抜いて抗を完成する・ペ， 一ト抗は89本打ち, その上に基礎土盤を乘せている図 （4・5）ただべノート抗は湧水個所および地盤疎部に対し てはモルタル注入の必要があり, 伏流水の流速 $6 \mathrm{~mm} / \mathrm{s}$ 以上になるとモルタルが流され，注入が困難となる。

新設高炉では炉底の温度上男によるコンクリートの脆 化を防ぐため，基礎上部にパイプを通し空冷したりまた は定盤の下部に水を流して冷却するなど種々の工夫がな されている. また基礎上部に叫部を設けて，この部分に 耐火俩瓦を積み，できる限りコンクリート部分が高温に さらされないよ5满築されている。

\section{$4 \cdot 1 \cdot 3$ 礿体鉄皮および本柱}

高炉の炉容の增大，捲揚装入回数の增加に伴ない，捲 揚装置, 炬頂装入装置などを 4 本柱で支持する方式が数 多く採用され，炉体鉄皮で炉頂棈造物を支持するいわゆ る米国式は順次廃止されつつある.

4 本柱はラーメン棈造と, トラス構造とがあり, 新設 高炬では前者が大半を占めている.

炬体の鉄皮構造は炉腹部より上部の鉄皮, 煉瓦積を支 柱で支持する方式と，4 本柱のリングガーダーで支持す る方式, さらにこれらの支持方式のないフリースタンデ イング方式とに分かれるが，鉄皮はいずれも溶接組立が 主体をなし，炉胸部および炉腹部には開放型あるいは密 閉型の冷却板が全体にわたり, 插入され，煉瓦積の冷却
ならびに支持に役立つている・炉胸部における鉄皮の厚 さは 20〜30 mm に達している.

朝顔部の鉄皮はフリースタンディング式では40〜 $50 \mathrm{~m}$ $\mathrm{m}$ と相当厚い鉄皮が使用されているが，炉腹部より上部 を支持する方式ではいわゆる朝颜マンテルの鉄板は比較 的薄くなつている. 泠却方法としては昫胸部と同じく冷 却板を雨入する方法と撒水方式とがあるが, フリースタ ソディング式は鉄皮の強度上冷却板插入方式をとること が難かしい、いずれにせよ朝顔部の泠却方式には末だ決 定的なものがない.

炉底部の鉄皮は45〜60 mm の厚板が使用され，大部分 は電気溶接構造となつている. 冷却方式はほとんどが表 面散水によつており, ジャケット方式のものは見られな い. 出銑口周曲には銅製の密閉型冷却板を插入して冷却 しているものと, ジャケット式の泠却装置を設けたもの, あるいはこれらを全く久くものと種々あるが, 大型炉に おいては大半泠却装置を有している.

羽ロマンテルについては銅製密閉型冷却板を插入して 冷却しているものと,ただ表面散水方式により冷却して いるものと 2 つの方法が見られる. 泠却水は水量, コス トの面から海水を使用している炉が多い，淡水使用炉で 部分的に循環使用しているのみである.

送風羽口の数は炉内容積約 $700 \mathrm{~m}^{3}$ の炉で 14 本, 約 1,000 $\mathrm{m}^{2}$ の炉で16本, 䄪 1, 600 1,700 $\mathrm{m}^{3}$ の炉で18〜20 本, となつてお门, 羽口径は $150 \mathrm{~mm} \phi$ を主とし, 一部 では楕円形羽口を使用している炉もある・材質は純銅鋳 物で, 送風羽口の個数は M. A. PAVLOFF の式:こよれば $\mathrm{n}=2 \mathrm{D}+1$ ( $\mathrm{D}:$ 炡床径 $(\mathrm{m}))$ である。この式は通常操業 の高炉に適用され, 高圧操業の炬に対しては羽口数 $\mathrm{n}=$ 2D の式が示されている. わが国の高炉の場合, ほとん どこの式に当てはまつている. 高炉の重油, コークス炉 ガスなどの燃料吹込みに伴ない，吹込用ノズルを有する 羽ロも使用されている。

\section{$4 \cdot 1 \cdot 4$ 炬体煉瓦積}

高炉の炉容の增大, 冷却方法の改善などとあいまつて 炉体の煉瓦積についても種々の改良がなされ，カーポン 煉瓦の採用, シャモット煉瓦の品質向上に伴ない, 灯壁 の厚さも可能な限り薄くしょ５とい5傾向が出ている. 一方 $\mathrm{Co}^{60}$ などの放射性同位元素を利用し炬内煉瓦潄の 摩耗状況を監視するなど煉瓦積に対しては多大な関心が 払われている。

炉休部の煉瓦積には最近の炬ではほとんどカーボン煉 瓦を採用し、炉底ならびに湯溜外周部に使用されてい 


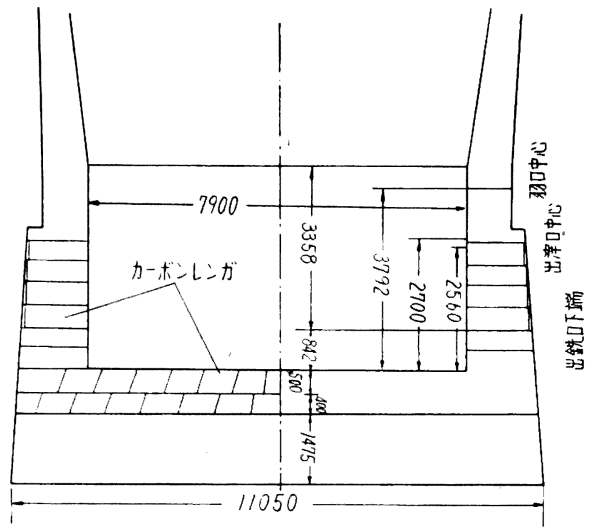

図 4.6 妇底のカーボンレンガ

る.八幡洞盛第 4 高炉の炉底カーボン煉瓦使用状況を図 示すると図 4.6 のごとくである.

炉底下部にはシャモット煉瓦を使用している．出銑口 出滓口ならびに羽口迥りには大型異形徚瓦を使用し，煉 瓦樌作業の迅速化を計り切付による煉瓦の劣弱化を防止 している.

炬東部の炡瓦䆅の摩粕に対しては各所とも重大な関心 を厸い， $\mathrm{Co}^{80}$ などの放射性同位元素を炉底ならびに湯 溜部の煉瓦積の各所に埋込又, 外部より $\gamma$ 線の強度を測

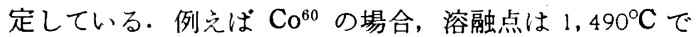
半減期 5.3 年, $1.1 \mathrm{mev}$ および $1.3 \mathrm{mev}$ の $\gamma$ 線を放射 し，鉄と容易に合金を作る。したがつて煉瓦の損賃によ り $\mathrm{Co}^{60}$ が生成銧鉄とともに灯外に流出すれば，銑鉄中 の放射能検出, または埋込灭筒所に抢ける放射能の変化 を外部から測定して煉瓦の摩耗を知ることができる.

朝顔部および炬腹部の煉瓦積については, カーボン煉 瓦の使用も試みられているが多くは比較的高級なシャモ ット煉瓦を使用し，俩瓦の原料は主に米国より輸入した 高アルミナのシャモットを使用し国内で焼成したものを 使用している.炑瓦䅡を保護するために密閉型冷却板を 挿入したりまたは表面撒水方式によつて冷却を行なつて いる.灯胸部の煉瓦積は最近の灯ではほとんど全体にわ たり開放型あるいは密閉型の泠却板を㨂入し, 煉瓦の泠 却ならびに脱落防止を計つておう, 炬胸下部においては 朝顔部抢よび炣腹部と同樣なシャモット煉瓦を使用して いる炉が多く，炉胸上部はこれに比しやや品質の少る国 内産原料によるシャモット煉瓦を使用している.

炬体各部に使用されている耐火煉瓦の物理的化学的性 状を例を挙げて次に示す.

(1) カーボン䗲瓦

カーボン煉瓦は炬床部のみならず朝顔ならびに炉腹部
にも将来使用範囲が拡大されることと思われるが，装入 物の化学的拉よび物理的な浸食に対し非常に強い抵抗力 を持つている. また耐圧強度は温度変化に対し極めて安 定性があり熱膨張係数は非常に小さく, 熱伝導率は温度 の上年とともに減少している. 反面, カーボン煉瓦は $\mathrm{O}_{2}, \mathrm{CO}_{2}$, 水蒸気による酸化に対しては抵抗力は弱い，乙 たがつてカーボン㱫瓦の厚さは比較的薄くできるが, 空 気や水の侵入は避けねばならない，次にその使用例を示 す.

富士室蘭第 2 高灯 日本電極脷製

使用原料焙烧特㷠製 無煙炭 黒鉛 ピッチタール 司コークス

配合割合 57\% $5 \% \quad 20 \% \quad 14.5 \% \quad 3.5 \%$ 尼鉄第 2 高炉 カーボン燀瓦性状

水分揮発 灰分 固定 見掛 真比気孔抗圧力

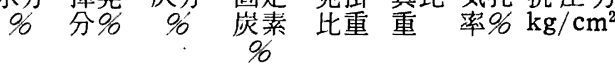

$\begin{array}{llllllll}0.10 & 0.72 & 2.98 & 96 \cdot 20 & 1.636 & 1.983 & 17 \cdot 5 & 425\end{array}$

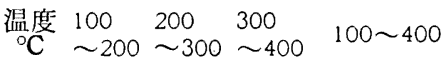

$\begin{array}{lllllll}\text { 熱係 } & \text { L } & 5.03 & 5.46 & 5.73 & 5.41 & \text { 加圧方向 } \\ \text { 膨 } & \text { R1 } & 4.69 & 5.08 & 5.50 & 5.09 & \text { 加圧直角方向 } \\ \text { 張数 } & \text { R2 } & 4.13 & 4.75 & 5.14 & 4.67 & \\ \text { (2) } & \text { シャ モット 㷄瓦 } & & & \end{array}$

シャモット煉瓦はカオリン鉱物を主体とする含水珪酸 フルミニウム質耐火原料を使用している．最近高炉使用 シャモット煉瓦の粘土質原料として米国よりフリントク レーが輸入されわが国において混練焼成されている.フ リントクレーは 2 次生成硬質粘土であるが，可塑性が少 なく微粉破する必要がある. 粘土質原料は一般に乾燥収 縮, 焼成収縮が大きいので龟裂を生じたり，寸法型状が 不正確になるので一度焼成した後, これに軟質粘土, 特 に可塑性のある粘土を混合して使用する必要がある. 次 にその使用例を示す.

富士・室䕥第 2 高炉

\begin{tabular}{|c|c|c|c|c|c|}
\hline $\begin{array}{l}\text { 使 用 筒 所 } \\
\text { 配 合 原 料 }\end{array}$ & 炉 底 & $\begin{array}{l}\text { 炉底 } \\
\text { 下部 } \\
(\mathrm{S})\end{array}$ & 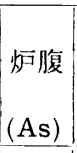 & $\begin{array}{l}\text { 湯溜, 朝 } \\
\text { 嵃および } \\
\text { シャフト } \\
\text { 下部 } \\
\text { (A) }\end{array}$ & $\begin{array}{l}シ ャ フ \\
ト \text { 上部 } \\
\text { (B) }\end{array}$ \\
\hline フリントクレー筦 & $55 \%$ & $65 \%$ & $30 \%$ & $30 \%$ & \\
\hline シリマナイト焼 & $10 \%$ & & & & $15 \%$ \\
\hline $\begin{array}{l}\text { ロー.フリントクレ } \\
\text { 一焼 } \\
\text { ソフト.フリントク } \\
\text { レー㳳 }\end{array}$ & $35 \%$ & $\begin{array}{r}30 \% \\
5 \%\end{array}$ & $60 \%$ & $65 \%$ & \\
\hline 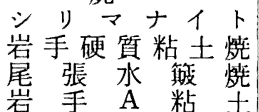 & & - & $\begin{array}{r}10 \% \\
-\end{array}$ & - & $60 \%$ \\
\hline 磐城水䈱粘土 & - & - & - & - & $10 \%$ \\
\hline
\end{tabular}


尼鉄第 2 高炉

\begin{tabular}{|c|c|c|c|c|c|c|c|c|c|}
\hline 使 用 籄 所 & 出涬口銑付近 & $\begin{array}{c}\text { 朝 顔, } \\
\text { 古 }\end{array}$ & $\begin{array}{l}\text { 炬 腹 } \\
\text { フ }\end{array}$ & $\begin{array}{l}\text { 部 } \\
\text { 部 }\end{array}$ & $\begin{array}{l}\text { シャフト } \\
\text { 中央部 }\end{array}$ & \multicolumn{2}{|c|}{ 炉底部下積 } & \multicolumn{2}{|c|}{$\begin{array}{l}\text { 灯頂および } \\
\text { シャフト上部 }\end{array}$} \\
\hline Ig. loss $\%$ & $0 \cdot 30$ & 0.32 & $0 \cdot 31$ & 0.28 & 0.24 & 0.18 & 0.32 & $0 \cdot 24$ & 0.24 \\
\hline $\mathrm{SiO}_{2} \not 6$ & $52 \cdot 88$ & $52 \cdot 02$ & $53 \cdot 27$ & $54 \cdot 31$ & $54 \cdot 50$ & $54 \cdot 41$ & $54 \cdot 59$ & $54 \cdot 82$ & $55 \cdot 88$ \\
\hline $\mathrm{Fe}_{2} \mathrm{O}_{3} \%$ & $2 \cdot 45$ & $2 \cdot 50$ & $2 \cdot 56$ & $2 \cdot 57$ & $2 \cdot 68$ & $2 \cdot 88$ & $2 \cdot 96$ & $2 \cdot 55$ & $2 \cdot 70$ \\
\hline $\mathrm{Al}_{2} \mathrm{O}_{3} \%$ & $43 \cdot 32$ & $43 \cdot 84$ & $42 \cdot 82$ & $41 \cdot 39$ & $41 \cdot 20$ & $41 \cdot 28$ & $40 \cdot 97$ & $40 \cdot 64$ & $39 \cdot 65$ \\
\hline $\mathrm{CaO} \%$ & 0.22 & 0.05 & 0.42 & 0.35 & 0.41 & 0.47 & 0.25 & 0.42 & 0.33 \\
\hline $\mathrm{MgO} \%$ & 0.27 & $0 \cdot 50$ & $0 \cdot 18$ & 0.22 & 0.50 & $0 \cdot 43$ & $0 \cdot 31$ & 0.39 & 0.29 \\
\hline $\mathrm{MnO} \%$ & $\operatorname{Tr}$ & $\operatorname{Tr}$ & $\operatorname{Tr}$ & $\operatorname{Tr}$ & 0.23 & $\operatorname{Tr}$ & $\operatorname{Tr}$ & 0.23 & $\operatorname{Tr}$ \\
\hline 耐火度 S.K & 33 & 33 & - & 33 & 33 & 33 & - & 32 & - \\
\hline 吸水率 $\%$ & $7 \cdot 46$ & $7 \cdot 47$ & - & $7 \cdot 20$ & $6 \cdot 88$ & $7 \cdot 30$ & - & $6 \cdot 79$ & - \\
\hline 気孔率 \% & $16 \cdot 2$ & $16 \cdot 5$ & - & $15 \cdot 6$ & $15 \cdot 0$ & $15 \cdot 8$ & - & $14 \cdot 7$ & 一 \\
\hline 㡀比率 \% & $2 \cdot 16$ & $2 \cdot 18$ & - & $2 \cdot 19$ & $2 \cdot 18$ & $2 \cdot 18$ & - & $2 \cdot 18$ & - \\
\hline 見掛比重 & $2 \cdot 55$ & $2 \cdot 60$ & - & $2 \cdot 60$ & $2 \cdot 57$ & $2 \cdot 58$ & - & $2 \cdot 55$ & - \\
\hline 耐火強度 $\mathrm{kg} / \mathrm{cm}^{2}$ & 442 & 478 & - & 573 & 615 & 580 & - & 618 & - \\
\hline
\end{tabular}

\section{$4 \cdot 2$ 巻揚装入装置}

高炉内に拈ける装入物の分布を良好なものとすること は炉内に打けるガス流を均一にし，炬況を安定させる上 に極めて重要である．従来炉頂装入装置についてはわが 国の高炉ではバケット式によるシングルベル，分配装直 付による方法とダブルベル，旋回ホッパー方式すなわち マッキー式装入装置による方法との 2 つた別されてい る。

最近の新設高炉では炉容の増大に伴ない, 装入鉱石量, および装入速度の增加が要求され，自動装入制御方式の 発達とあいまつて必然的にスキップによる斜塔捲揚方式 が多く採用され，バケット方式による捲揚装置に新設高 炬では皆無で従来の中小型炉にその型式を留めている. さらに立地条件によつて高炉と貯鉣槽の関係位置が制約 を5ける所ではベルトコンベャ一方式による捲揚装置を 採用し設備費の軽減, 港揚速度のスピード化を計つてい る.

撩揚装置のこのよ5な变遷に伴ない炬頂装入装置はス キップ方式でダブルベル方式のマッキー式旋回装入装 置, またベルトコンペャ一方式ではそれぞれ独自の旋回 装入装置を採用している。

\section{$4 \cdot 2 \cdot 1$ 撩揚装置}

（1）斜塔スキップ式捲揚装置

この装置は鋼製の傾斜塔の軌道上を 2 台のスキップ (鋼製の箱車) が交互に年降し，炉頂で反転して貯鉱槽 から切出して塔載してきた装入鉄鉱石またはコークスを 装入ホッパーに入れるようになつている・スキップの年
降はワイヤーロープで捲揚機により運転される・

貯鉣槽のピットと高炉々頂との間に架設される傾斜塔 の傾斜角度は $55 \sim 57^{\circ}$ 位が普通である. 構造はワーレン 型トラス構造, ワーレン型ラチス構造およびプレートガ 一ダー構造などの型式がとられている.

スキップ容量は高炉の出銑能力により左右されるが全 般に大きくなる傾向があり，炉内容積約 $700 \mathrm{~m}^{3}$ の炉で は 6 8 $\mathrm{m}^{3}$ 約 $1,000 \mathrm{~m}^{3}$ の炉では $10 \sim 12 \mathrm{~m}^{3}, 1,600 \mathrm{~m}^{3}$ 以上の大型炉では約 $16 \mathrm{~m}^{3}$ を採用している.

スキップの界降に使用される捲揚機は長期間ほぼ連続 的に重荷重で運転される故, 保守が容易で故障が少なく また大容量のものが要求される. 型式としては単胴型ま たは複胴型で主埢直流電動機 2 台による同時駆動方式を 採用しているのが多い. 出銑能力 $1,000 \mathrm{t} / \mathrm{d}$ 以上の大型 炉では使用している主捲電動機の容量は200〜250 kW と なつている.高炉の出銑能力の増大傾向に備えてスキッ プの捲揚速度も余裕を見て大きくとつて扣り，八幡戸畑 第 3 高炉ではスキップの最大捲揚速度は, $120 \mathrm{~m} / \mathrm{mn}$ に 達している.捲揚機の速度制御には制御箸囲が広く電力 損失の少ないワードレオナード方式が多く使用され，炉 頂装入装置および詝鉣榑, 貯骸槽の切り出し装置ととも に自動制御運転されている，たたこの方式では主挖值流 電動機に直流を供給するため, 別に直流発電機拉よびこ れを駆動するための三相誘導電動機, さらに直流発電機 用の励磁機など設備費が膨大となるため，中小型灯では 挖揚機に交流電動機を使用しているものもある.

尼鉄第 1 高炉のスキップ撩揚機は主捲電動機に $160 \mathrm{~kW}$ 三相誘導機と主捲電動機制御用に $95 \mathrm{~kW}$ 交流制動機を 使用している．従来交流電動機の速度制御は直流電動機 
に比し困難であり，容量的にも制約をうけた。ここに採 用された交流ブレーキ制御方式の特色を述べると次のご とくである.すなわち交流誘動電動機の起動によりギャ 一を介してドラムが回転し同時にパイロット発電機が発 電し電正を発生する.これと基準速度指令電王（基潗速 度指令周抵抗器のスライド電圧) を初段磁気增泭器の 制御コイルを通して突合せ呵者間の偏差があれば初段磁 気增幅器がこれを增幅し, 次に次段磁気增幅器で再び增 幅し $5 \mathrm{~kW}$ 励磁機の界磁を励磁し, $95 \mathrm{~kW}$ 交流制動機の 界磁電流を增減して制動力を加減し, 電王負荷の変動に 対するスキップの速度変動を微少にする仕組となつて いる.

この方式の利点としては低高速の設定が容易であるた め装入行程に拈ける時間を延長あるいは短縮する場命, 他の制御機壖よりも非常に楽にこれを調整することがで きる・また主電動機および交流制動機に付与寸る電流付 与時間の調整が容易である. 欠点としては父流制動機 の容量が比校的大となり捲掦機据付場所が余分に広くな る.また交流制動機であるため余り電動機の容量を大に することは多少難点がある・

住金小倉第1高灯では同じく交流電源をスキップの范 揚動力に使用しているが,これは主撩誘導電動機にリア クターを使用して自動運転を行なつている，従来誘導電 動機の欠点としては2 次抵抗による速度制御を行なつた 場合, 負荷回転力の変化による速度変動率が大きく, 無 負荷の場合は機械制動機を併用しなければ低速運転がで きないことおよび負の回転力の場合, 同期速度以下では 運転できないことである.リアクトルコントロール方式 を採用した場合の利点は次のよ5にいわれている.

a) 必要に応じて制御段数を幾らでも取り得るので微 細なコントロールが可能である.

b) 制御把手のあるノッチに対して電動機負荷の大． 小, 正・負，に拘わらずほとんど一定速度で運転する.

c）負荷回転力の正負による電動運転へある制動運動 から移行するのに回路の切替を要せず自動的連続的に行 なえる・

d) 制御量の損失が少なく電力料が安価である.

e ) 従来のものに比べ設備料が安く保守が簢単に行な 觉る。なた危険率が低い。

（2）ペルトコンペャ一式港揚装置

貯鉣場その他高灯周辺の工場設備の関係から貯鈗槽を 高炉の近傍に直くことが困難な場合, また工場内敷地の 起伏を利用し整地作業費を削减し貯鉱槽ならびに高炉 設備が建設可能な場合には設備費が僅か?ですみ, 自動運
転制御装置も簡単になり非常に有利な原料般送装置であ る。

代表的な例として大阪西島第 1 高灯のペルトコンペャ 一方式を取り上げてみると，貯捈槽，貯骸槽に就ける原 料切出し設備から炉頂装入装置まで自動運転制御されて いる.眝鉱槽または眝䞄槽から切出された装入原料は 2 条の傾斜装入ベルトコンベャーで炉頂装入装監の旋回シ ュート内へ装入され，さらに原料はこのシュートから上 ベルホッパー内に連続的にかつ均一に装入される。装 入コンベャーの駆動には $50 \mathrm{~kW}$ の全閉籠型電動機を使 用し，流体接手少よび自動近転防止装置を取付けてい る.運転方式には自動, 連動および単独運転の3方式が あり，自動運転とはあらかじめ決められた装入スケジュ 一ルに従つてサウンジング装置よりの信号により原料切 出, 装入サウンジングの動作を全て自動的に行なももの である．連動運転はこの自動運転の5ち装入開始をサウ ンシンンク装䈯よりの信号によらず連動押釦によりチャー ジの装入を行な5ものである，単独渾転は個々の動作を それぞれの押釦により別個に運転するものである。

\section{（3）バケット式撩揚装置}

この装留は従来中小型炉に多く見られ最近の新設高炉 ではこの方式をとるものは無い，バケット式では傾斜塔 もしくは垂直水平塔により装入車でバケットを吊し地上 の科量車またはターンテーブルから炉頂に撩揚げてバケ ットと装入物の自重によりバッッ下部が開き，炉頂の 装入ペルを押開いて装入する方法である.

ハケット式では傾斜塔式, 重直水平塔式に拘わらず平 衡鋵を設けることにより，捲揚機の動力を節約できる装 入車があるためスキップ式に比べ鉄骨構造を禎丈にする 必要がある. また装入車によるバケット移動時の振動防 止の点から装入速度に限度があり，またスキップ式のよ 5に往復とも装入に利用することが，不可能で师頂から の帰還時は装入口スとなる．地上で装入原料をバケット に入れる際にはターンテーブルでパケットを旋回させ， 均一に分布さす必要がある，その代わり炉頂における装 入装置が簡単となり, 旋回ホッパーは設ける必要がなく この点設備費補修費の節約となる.

バケット式を採用した場合の炬頂装入装置としてはシ ングルベル方式またはダブルベル方式がある.

捲揚機はスキップ式と同じく主捲電動㙨に淔流を使用 し、ワードレオナード方式による速度制御を行ない, 自 動運転制御を行なつている.

\section{$4 \cdot 2 \cdot 2$ 炉頂装入装置}

灯頂装入装置は種々の方法があるがいずれも撩揚げら れた装入原料を炉内に均一に分配するとともに炉頂装入 
ロからのガスの漏洩防止をはかつている.

代表的な例としてはマッキ一式旋回装入装置がある が，これは傾斜塔スキップ式撩揚装置に付属する装置で

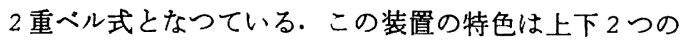
ホッパーを有し，上部のいわゆる小ペルホッパーがスキ ップからの装入原料を受けた後電動機により旋回するよ うになつている. 旋回角度は装入スヶジュールに従つて 種々選択ができ，また一定の周期に従つて変化させるこ ともできる.下部のいわゆる大ベルホッパーは小ベルホ ッパーで受けた装入物を1ないし数回分まとめて炬内に 装入する役目を果すとともに大ベルによつて炉内ガスの 漏洩をも防止している. 通常小ペルホッパーから2 回装 入されて大ベルが 1 回開き炉内に装入物が装入される. そして大へル 2 回開くことにより，1チャージ分が装入 される.

マッキー式装入装置では旋回ホッパーの回転部分のガ ス漏洩防止が重要視され大半のものがグリースシール式 を採用している．また一部では水封式のものも見られ る. この装置に付属している大小ベルの開閉には電動ク ランク式とェャシリンダー式の 2 種の開閉機が主に使用 されている. 前者は撩揚機室に設置された電動式クラン

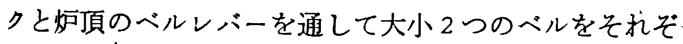
れ 2 本のワイヤーロープで連絡し, クランクの回転に伴 なつてベルが開閉する構造となつている. 後者は捲揚機 室のエャーシリンダーと炉頂のベルレバーを通して大小 ベルをワイヤーロープで連結しエャーシリンダー内のピ ストンの上下により作動する方式である. しかし空気圧 式であるため, 幾分閉止時の衝撃がラランク式に比べて 楥和される。

港揚装置がバケット式の場合には前述のように炉頂装 入装置としてはバケット内の装入物の自重によりパケッ トの底蓋が開くと同時に炉頂のペルを押し開き装入物を 炬内に装入する方式をとつており，この場合炉頂のベル はカウンターウェイトにより閉止動作を行ならようにな つているままた炉頂ベル大きさを小さくし，炣内に拉 ける装入物の分布を均一にするためディストリビュータ 一を装置しているものもある.

ベルトコンベャーにより装入物が炬頂に捲揚げられる 方式では, 旋回シュートを備えた方式また 2 重ベル式で 旋回ホッパーを備えた方式などが考えられている・わが 国の例では前者が挙げられ，これは旋回シュートを備え て装入物がこれより固定ホッパンの小ベルの上に均一に 分配装入し，1スキップ分に相当する量の原料を装入し 終れば，小ベルを開閉し，大ベルホッパーに装入してい
る.大ベルは小ベルホッパー2 回分を装入し終れば1回 開閉し炬内に装入し，大ベルホッパー2 回分の装入物量 が1チャージに相当する.この方式ではマッキー式のよ ろに小ペルと小ベルホッパーを旋回させないので旋回部 分にガス漏洩防止装置が不要となり設備が簡略化され る.また大小ベルの開閉はロッドを介してバランスレハ 一およびクランクに連結し電動により行なつている. 後 者の方法はマッキー式と同じく旋回ホッパーを有し固定 シュートより落下した装入物がこの中に均一に分配され た後, 上ペル拈よびガスシール用の下ベルを開いて炉内 に装入される。

炉頂装入装置としてはこの外にブラウン式, マッキー 式の改良型， 3 重ペル方式と種々の方法が考えられてい るが最近に括けるわが国の新設および改修言炀では大半 が斜塔スキップ式捲揚機と関連しマッキー式旋回装入装 置を採用している.すなわち高炉の出銑能力の増大に伴 なら装入速度のスピード化が主な採用原因となつてい る.

\section{$4 \cdot 2 \cdot 3$ 秤量装置}

装入鉱石およびュークスの科量は高炉操業技術の進歩 とともに近来精度の向上が望まれ，人為的または機械的 な誤操作による切り間違いおよび誤差の介入を防止する よう考虑されている. 従来コークスの科量は主にホッパ ースケールが使用されていたが，貯鉱槽から鉱石を切出 し科量するには主にラリーカーすなわち科量車が使用さ れ新設高炬でもこの方法を多く使用している. 科量車に 使用される科量器は使用場所ならびに使用状況から堅牢 性および走行に伴な弓衝媻に充分耐える精度をもつよ5 要求される。このような観点から走行中または原料受入 時の振動防止のため車体と科量ホッパーとの間に防震ゴ ムなどの緩衝器をおく車が多くなつている. 使用科量器 としてはダイヤル積算式の自動指示記録装置付のものや ロードセルあるいは捍無鉡式, 双振子自動式など種々の ものが挙げられるがダイヤル積算式のものが多い科量 能力はスキップの容量によつて左右されるが最大科量約 20〜40 t を示しておりり科量ホッパーの大きさは 8 $12 \mathrm{~m}^{3}$ である・ホッパーの底屝開閉は圧縮空気式によるものが 多い.

コークスの科量は眝䟺槽から切り出されたコークスを 適当な網目の篩で篩分けた後, 塊コークスのみを科量ホ ッパーに受けて行なつているものが多い.したがつてこ れに使用される科量器は捈石の場合と異なり移動する必 要がないので精度ならびに設備の上に非常に有利で自動 
重量表示装置, 自動印字拉よび回数表示装置, 定量自動 停止装置など種々の付属機器を取付け自動運転制御に組 込まれているものが大半である. 秤量器の型式としては ダイヤル指示式のものが多い.

最近の新設高炉の中には従来の鉱石秤量車並びにコー クス科量ホッパーによつて装入原料を切り出す方法のほ かに高炬の出銧能力に応じて原料の切り出し科量速度の スピード化, 科量車操作時に括ける人為的誤差の防止, 捲掦装入装置と関連しての完全自動運転制御などを目的 として，眝鈗槽势よび眝骸槽から捲揚設備までの原料輸 送にベルトコンベャ一方式を採用するものが多くなつて いる. 日新吳第 1 高炬の例を挙げると、ここでは貯鉱槽 から電磁フィダーによつて装入捈石を科量ホッパー（自 動振子式）に受けて科量し，装入スケシュールにしたが つてペルトコンペャーに払出し，鉱石打込ホッパー（電 子管付秤量装置) か.らスキップヘ投入している.コーク スは貯骸槽より同じく電磁フィダーで切り出し, 途中グ リズリフィダーで笠分けた後, 塊コークスはベルトコン ペャーで科量ホッパーに送られ，科量後スキップへ投入 されている.

大阪西島第 1 高炉では䝪鉱槽, 貯䯓槽より電磁つィダ 一によつて装入原料を切り出し，これを各槽ごとに取り 付けられた計量機付ベルトコンペャーで所定量を計量 し，装入コンペャーに輸送されている，装入コンペャー は装入原料を炉頂まで直送し炬頂装入装置内のシュート 内へ装入している.これらの運転は全てコントロールセ ンターに执いて遠隔操作され, フィダー拉よび計量コン ベャーはあらかじめ設定された規定量を計量し終れば自 動的に停止する. コンベャ一計量の場合最も問題となる のは計量精度であるが大阪西島の場合, ペルトの速度, 制動装置などに工夫を施し、メリック計量機の規定精度 の 2.5 倍, $1 / 1500$ の精度を保証している.

\section{$4 \cdot 2 \cdot 4$ 自動運転制御}

最近に括故る計測制御装置の発達とあいまつて, 高炉 の出銑効率の增大, 高炉操業の安定, 鉄鉄品質の向上な ぞの技術的要望に応して, 高炉ならびにその付属設備に 自動運転制御装置が取り入れられる傾向は著るしい。

捲揚装入装置ならびに原料切り出し科量装置について も，ほとんどの高炬で自動制御を取り入れ，原料の切り 出しから炻内への装入まで完全自動制御化への傾向が見 られる. 原料の切り出し科量についても前述のよ5に従 来の秤量車に代わりベルトコンベャーによる輸送方法が とられ，一貫した流れをとつている.すべてこれらの装
㯰はあらかじめ決められた一定の装入スケジュールに従 つて行なわれ，運転状況は電光表示盤（グラフィクバネ ル）に表示される.

捲揚装入装膡の自動制御方式としては，モートルタイ マー方式あるいはロシット方式による全自動運転があ る. いずれも各チャージのスキップ数扰よび鉱石, コー クスの組合せを自由に容易に選択して行なうことが可能 であり，新設高炬では後者による方法が多く採用されて いる. しかしながら原料装入設備全般の完全自動運転制 御は数社に留つているにすぎない。

\section{$4 \cdot 3$ 送 風 設 備}

高炬用送風機は, 最近高炉の出銑能力の増大, 高温送 風, 然料吹込み扩よび高圧操業技術等の開発にともない 大容量かつ高圧の送風機が要求されている．また性能の 面に打いてもこれ等の情勢に対応して, 遠心式送風機よ り，軸流式送風機仁代わりつつある.

駆動用原動機としては，蒸気タービンが主であるが， 電動機, ガスタービンも使用されており出力は $4,000 \mathrm{~kW}$ 前後のものが多い.

最近の新設高炉では，多段式軸流送風機を採用する傾 向にあり, 最大送風量 $3,000 \mathrm{Nm}^{3} / \mathrm{mn}$ 以上のものも見 られ，原動機出力は $10,000 \mathrm{~kW}$ 近くにも達している. また, 高圧操業に備えて容積型に属するネジ送風機, （回転式送風機）を採用しているところもある.

\section{$4 \cdot 3 \cdot 1$ 送風機}

\section{（1）遠心式送風機}

これまでに使用されて来た遠心式送風機は，3段〜 4 段の片吸込み型，または両吸込及型で軸方向に流入した 空気を翼車で圧力を上げ半径方向に吐出させる型式の送 風機である.

この方式は, 比較的運転風量を広く取ることができ る.すなわち, 送風機特性図の吐出圧力一風量線図に拉 いてサージング限界線が低風量側に寄つているため, 余 裕ある送風が可能となる. 送風能力は最大風量 2,000 $\mathrm{Nm}^{3} / \mathrm{mn}$ を越光るものは少ない。

\section{（2）軸流送風機}

軸流送風機の特性は，遠心式にくらべて効率が良く小 型軽量で高速運転ができ大風量送風ができることであ る.また，風圧の変動によつて風量の変化が少ない，欠 点としては送風機特性図の吐出圧力一風量線図に打いて サージング領域が広く，常用籁囲が限界線近くにあるた め送風範囲に余裕が少ない。また騒音も高く翼の污損に 
ついても敏感でただちに効率の低下をきたす．騷音に対 する対策としては，吸入管，吐出管などに防音装置を設 㯰しておりまた吸入部には除郮装置を設けて翼の污損 を防ぎ効率の低下を防止し，連続運転にそなえている。 サーシングについては，ほとんどの送風機が自動防止装 置を設けており放風弁の開放によつてこれを防いでい る.

高炬操業の変動によつて送風量, 送風圧は変化する. したがつて送風機の送風点は高炉の能力を十分考虑して 決めねばならない，常用点を少風量にとれば，サージン グ限界も少風量側に寄り小風量領域では放風することな く，かつ効率良く運転することが出来る．乙かし送風量 が增すにつれて効率が低下するので原動機の出力を大き くする必要がある．逆に常用点を風量の大きいところに すれば原動機の最高出力は，比較的低く押えられるが， 少風量で送風する場合、サージングをさけるために放風 を行わ杖ならず効率の低下はさけられない。

高炉用大型軸流送風機としては, 昭和33年 2 月に八幡 洞岡に設置された $4,000 \mathrm{~kW}$ 蒸気タービン駆動のものが わが国では最初である.

\section{（3）齐シ送風機}

この送風機はスェーデンの Svenska Roter Maskiner 社が考案した容積型に属する回転式送風機で, 回転 する 2 本のローターの㗀み合いを利用して空気を移動さ せるとともに圧力を高める動作を行う。この動作は，口 ーター間拉よびケーシング間に小さな陌間を残し，接触 することなく行われる. ローターの歯形については種々 のものが考案されたが現在では，大部分が円弧より成る 対称形のものとなつている．また定容積型であるためサ ージング限界がない，その他の利点としては，他の送風 機にくらべて除壁装置が簡単なフィルターで十分であり かつ, 構造が簡単であるため設供費も安く保守も容易で ある.しかしながら欠点としては、サージングが無いた め高炉の炉況変化により通風抵抗がまし，風圧がまして も，絶えず一定風量が送られるので吹き抜けを生ずる恐 れがある．また比較的騒音が多く消音装置に工夫が必要 でありとくにサイレン音が問題となつている．この騒音 は, 周期的に吸入, 吐出される空気により発生し, この 脈動にもとずく配管の振動も問題となる。サイレン音は 周波数が低いため消音が難かしい，性能の面では大型軸 流送風機と比較した場合効率の点で十分対抗し5るし， 遠心式送風機よりも良好であるといわれている。この形 式の送風機は, 神鋼・神戸第 2 高炬用送風機として採用 されている.

\section{$4 \cdot 3 \cdot 2$ 原 動 機}

送風機の駆動用原動機としては，大半が蒸気タービンを 使用し一部に電動機, ガスタービンが使用されている.

(1) 蒸気タービン

蒸気タービンを駆動用に使用した場合, 回転数を変え ることによりかなりの風量範囲の操業が可能で効率の面 で有利となる．従来は低王蒸気が使用されてきたが効率 の面で劣り最近では高圧一高温の蒸気を使用するように なりトップタービン方式または抽気方式によつて熱効 率を高めている.この方式によれば低圧式にくらべ約 25 \%の効率上㫒が見込まれている.

\section{（2）電 動 機}

電動機は， $4,000 \mathrm{~kW}$ 以上の大型のものは見られず, いずれも誘導電動機が使用されている. 誘導電動機は構 造が比較的簡単で保守も容易であるが，回転速度制御の 面で種々問題が生ずる. 送風量を制御する場合回転数を 変えずにダンパーで制御すると，風量の作業籁囲が必然 的に狭くなり，動力損失も大きく運転量が高くつく，ま た回転数制御を行なつて風量を変化さす方法は, 誘導電 動機の型式によつて種々考えられているが，設備費は一 般に高くつく．しかし高炬のよ5に連続的に長期間使用 する場合は動力損失が少ないため有利である。

(3) ガスタービン

ガスタービンは，附属㙨械設備が簡単で運転費，補修 費もわずかですむ。 また同一送風条件でガスタービンは

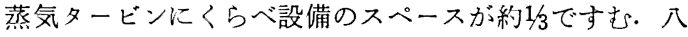
幡洞岡の高炉用送風機の駆動にガスタービンが使用され ているが，これは高炉がスを燃料とする $850 \mathrm{~kW}$ の開放 サイクルのものである．

ガスタービンは, 高温の排ガスによる熱量損失をカバ 一するため廃熱再生器を使用し効率の低下を防いでい る.しかしながら，ガス灰による污損のため高炉ガス圧 縮機の性能が低下し長期の連続運転を不可能にしてお り，全機関の熱効率は約 $13 \%$ でボイラ一迄含めた蒸気タ 一ビン駆動軸流送風機の全熱効率（約17\%）より幾分低 い值となつている，然料としては，高炬ガスが主なェネ ルギー源として使用されているが，高炉ガスの熱量低下 時, または起動時には, 高熱量の燃料例えばュークス炉 ガスを用いて熱量を補 う必要があろう.

\section{$4 \cdot 3 \cdot 3$ その他の付属設備}

送風設備における送風機，原動機には，それぞれに付 属設備があり効率の向上, 運転, 保守にその役割を果し 
ている. 以下八幡・洞岡の送風設備を参考にしてその概 要を示す.

\section{（1）消音装置}

一般に軸流式送風機は，遠心式にくらべ金属性騒音が 大きい、騒咅防止装置は吸込侧の消音室内面に取付けら れており, 騒音は80フォーン程度まで消している。 また 放風時の烈しい蹬音を消すため放風管出口にも消音器を 取付けている.

\section{(2) 除㦄装置}

送風機の翼に麼埃が付着すると効率が低下寸る。この 対策として消音室に続く除歴室内部に除麈装置を取付け ている.八幡・洞岡の軸流送風機は, アメリカン・エア ーフィルター社製のものを設置している.

(3) サージング防止装圆

この装犆は, 送風機の抵抗曲線が固有のサーシンング曲 楾に近ずく之，自動的に放風弁を開放して送風機がサー ジングに入ることを防止する.これはアスカニア式油圧 噴射装監を使用し放風弁に連動して扣り，操作盤より手 動で操作することもまた直接弁ハンドルで開閉すること も可能である.この装置は運転状態が図 4.7 (4.3.4 参 照）のサージング防止線上に来れば自動的に作動する.

（4）送風量制御

a 、定風量自動制御装置

この装固は, 高炉の圧力变動にかかわらずターピン の回転数を変化せしめることによつて常に風量を一定 に保つている・自動制御にはアスカニア式油圧貲射装 置を利用し，手動による遠隔操作も可能である.

b. 定風圧自動制御装置

この装孟は，風圧を常に一定に保たんとするもので 原理的には定風量の場合と同一である. 通常の送風状 態では，定風量装置で運転していて，熱風灯の切替時， 炉況不安定時などに定風圧装置に切替えて使用する。

c. .

駆動用原動機の回転速度制御が㹟い筪囲に限定され る場合，また，一定回転数の場合には，送風機の静翼 または動翼を可変ピッチとして効率をそれ程犠牲にす ることなく広範聿の流量変化に応ずる方法がある.こ の場合静翼のみを可变ピッチにする方が機能的にも構 造的にも比較的容易である.また送風機の軸端に一段 の動力回収用タービンを設けて余剩風量を通し動力を 回収する方法もある.

\section{$4 \cdot 3 \cdot 4$ 設 備 例}

（1）蒸気タービン駆動一軕流美風機例
一例として八憣・洞岡の送風設備の概要を示す.

a . 軸流送風機

（i）送風仕様籁囲

最大風量時 常用点 最小風量時

風 量 $\left(\mathrm{Nm}^{3} / \mathrm{mn}\right) \quad 2,000 \quad 1,400 \quad 1,000$ 昩出圧力 $\left(\mathrm{kg} / \mathrm{cm}^{2}\right) \quad 0.8 \sim 1.2 \quad 0.8 \sim 1.4 \quad 0.8 \sim 1.2$

(ii) 型 式 横置多段可動前置静翼付軸流式

(iii) 段 数 前置静翼 1 段 静翼 9 段 動翼 9 段 後置静翼 1 段

(iv) 翼材質 $13 \% \mathrm{Cr}$ 鋼

（v）前置静翼変節装置（手動式）

この装置は, 前置静翼の角度変化を行 うものであ るが，多段のために実際運転時には，あまり変化は 認められなかつた。

（vi） 送風機サージング特性

昭和33年 8 月 1 日の実測結果は図 $4 \cdot 7$ のよ5であ る.

（vii）送風機断熱効率

断熱効率は一般に送風機効率ともいわれ，因 4.8 にその実測値を示す.

b. $4,000 \mathrm{~kW}$ 蒸気タービン

（i）型式 衝動式值結型復水タービン

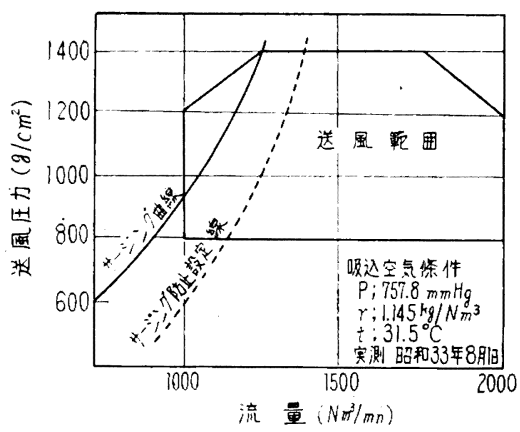

図 $4 \cdot 74,000 \mathrm{~kW}$ 軸流送風機サージング特性

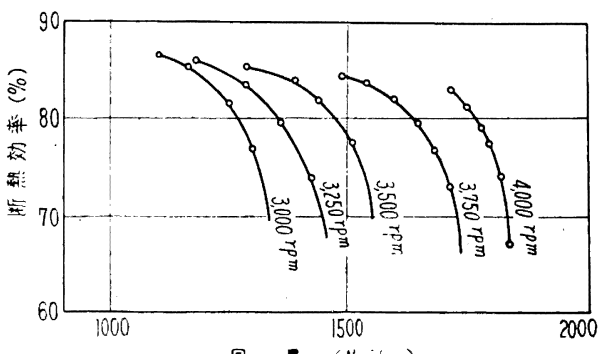

風 $\left(N \pi^{j} / m, n\right)$

因 4.8 送風機効率 
(ii) 出力および回転数

出力

回転数

常 用 点 $3,200 \mathrm{~kW} \quad 3,600$ r.p.m

最大連続出力 $4,000 \mathrm{~kW} \quad 4,020$ r.p.m

(iii) 蒸気状態（タービン主塞止并）

圧力 $\left(28 \mathrm{~kg} / \mathrm{cm}^{2}\right)$ 温度 $380^{\circ} \mathrm{C}$

(iv) 段落数9段（内1段はカーチス段）

(v) 危険回転数 4,900 r.p.m

c. 主な付属装置

消音装置, 除棌装置, サージング自動防止装置

定風量自動制御装置, 定風圧自動制御装置

d. 効 率

本設備を $1,000 \mathrm{t} / \mathrm{d}$ 高炉へ送風した場合の送風機効 率は平均約 $84 \%$ で従来の蒸気タービン駆動に上る遠心 式送風機にくらべ約 $10 \%$ も効湾が良く, さらに蒸気夕 ービンの熱効率が約 $25 \%$ で既設のもの上り約 $3 \%$ 程度 良好であり、したがつてプラント全体としての熱効率 は的 $21 \%$ ，ボイラー迄含めた全体の熱効率は約 $17 \%$ で 従来の設借上り100\%以上の動力節減となつている.

（2）蒸気タービン駆動一ネジ送風機例

一例として神戸灘浜の概要を示す.

型式 KS-80 L $\times 2$ 型

$$
\text { 6,000 P 蒸気タービン駆動 }
$$

容 量吐出圧力 回転数軸馬力 2, $100 \mathrm{~m}^{3} / \mathrm{mn} \quad 1 \cdot 33 \mathrm{~kg} / \mathrm{cm}^{2} \cdot \mathrm{g} \quad 3,026$ r.p.m 6,000 P $1,800 " 1 \cdot 80 " 2,635 " 6,000 "$

\section{$4 \cdot 4$ 熱 風 炉}

高炉操業にお汁る送風温度は, 羽口前の燃焼温度, 打 よび高炉内の温度勾配を左右する。また，その熱量は高 炉熱源として重要な役割を演ずることは周知のと拈りで ある. 高炉装入原料の事前処理の不完全な時期に打いて は, 炉内の通気性が極めて不安定で荷の降下状態が不規 則となるため、コークス装入量を節减するための高温度 の熱風の使用は不可能であつた．それで5〜6年前までの 送風温度は $800^{\circ} \mathrm{C}$ 以下の低い温度で高炉操業が一般に行 われていた。このような比較的低い送風温度による操業 期に打いては熱風炉の設計において，大巾な進展はみら れなかつたので，送風温度が逐次上界するにしたがい熱 風炉の容量の不足が感ぜられてきた。したがつて最近建 設された熱風灯は過去のものに比較して非常に大型化し ている.さらに: $100^{\circ} \mathrm{C}$ 以上の高温の熱風を使用するた めには充分な検討を行なつて設計する必要がある。しか 乙熱風炉の取扱いに関する装置, 寸なわち自動切替, 自 動然焼制御設備などの改善には見るべきものがあつた。
過去数年の間に高炉操業技術は著しく飛躍し完全に処 理された整粒鉱と，自溶性蟯結鉱の使用は炬内通気性を 改善して高温送風の実施を極めて容易にし，また水蒸気 添加による調湿送風ならびに然料の吹込みは羽口前の分 解反応熱を補償するために益々高温送風を直接に必要と するよ5になつた．また邩内通気性の好転と還元反応速 度の向上は, 送風量の增大を可能にし，ここにおいて熱 風炬の熱負荷は大巾に增加した，一方高灯操業成績の向 上は相反的に高师ガスカロリ一値を低下し燃料としての ガス量を著しく增加した。この結果過去の設計による既 設の熱風炉の熱効率は低下しバーナー容量と熱容量に限 界を生じ高炉操業に扣㚈る送風量, および送風温度指定 值は熱風炬能力の限界により規定される傾向となつた。 しかしこの間に批いても熱風灯に関寸る伝熱工学部門の 研究が活発に行われ萻熱室㶱瓦形状, 伝熱面積扣よび煉 瓦重量などの決定に有効に活用された．また耐火物の耐 熱性, 弁関係の設借の耐熱, 大型化, 拈よび運転操作機 構に関する研究も進められ, 燃焼火炎温度の上䄯に対す る対策も考えられるよ5になつた．かよ5に熱風炬設備 は，高温送風を可能にし熱容量の增強のために次第に大 型化の傾向に進み始めている.

\section{4·4・1 熱風炉設備における伝熱学適用の現況}

熱風炉の設計に括いては高炉操業条件に基づき，次に 示す重要事項を満足するように先ず検刢しなければなら ない。

（1）目標最高熱風温度と送風量に対する加熱能力

（2）高い熱効率の保証

（3）適正な蓄熱容量の保有

(4) 設備費の軽減

（5）耐久性の保証

これらはいずれも伝熱工学に基つう，熱伝達率，加熱 面程，荒熱室棣瓦形状，材質ならびに通気面積などの解 析により検討されるものである．熱風炉の形式としては 従来から再生型熱交換器が使用され高炬 1 基に対して, 2〜4基の炉を装诮し，高炉操業条件に応じて，燃焼がス 量, ならびに燃燒・送風の周期を決定し操業している. 現在では熱風䏓の大型化にともない，Cowper 式熱風炉 が普及している：しかし熱風炉の熱伝達状態は極めて複 雑である・たとえば，然燒期では㭁の上部の高温度部に 扣ける伝熱は，主として輻射により行なわれ，灯の下部 の低温部では対流が重要である.すなわち炬の糈方向に 捄ける温度公配に上り，熱伝達特性が変化する。また， 同位置における温度は, 燃焼期, 通風期の経過時間によ 
りガスおよび徚瓦ともに変化し，非定常状態として，等 風炉の熱伝導を考えねばならぬ.このため理論的に熱風 炉の伝熱を解明することは極めて困難な問題であつた. そして過去20〜30年間において多数の研究者によつて理 論的に熱風炉の伝熱機構についての解析が行なわれたが これらはいずれもそのまま炉の設計に使用することには 少し無理があつた. しかし熱風炬の設計に極めて効果が あつたことは事実である．次にその1例を熱風炉 2 基操 業の場合について示すことにした。

先ず高炬操業条件（送風量, 熱風温度）を決定し, 過 去の操業実績ならびに将来の技術を予測して高炬ガスの カロリ一値, 熱風炉熱効率を仮定すると, 熱風炉の加熱 に要するガス量： $\mathrm{V}_{\mathrm{G}}, \mathrm{m}^{3} / \mathrm{cycle}$ は次式により与えられ る.

$$
\mathrm{V}_{\mathrm{G}}=\left\{\mathrm{V}^{\prime} \cdot \mathrm{C}^{\prime} \cdot\left(\theta_{2}{ }^{\prime}-\theta_{1}{ }^{\prime}\right)\right\} / \eta \cdot \mathrm{H} \cdot \mathrm{t}
$$

$\mathrm{V}^{\prime}$ : 送風量, $\mathrm{m}^{3} / \mathrm{cycle}$

$\mathrm{C}^{\prime}$ : 熱風の比熱, $\mathrm{kcal} / \mathrm{m}^{3 \circ} \mathrm{C}$

$\theta_{2}{ }^{\prime}:$ 熱風温度, ${ }^{\circ} \mathrm{C}$

$\theta_{1}{ }^{\prime}:$ 冷風温度, ${ }^{\circ} \mathrm{C}$

$\eta$ : 熱風炉の熱効率

$\mathrm{H}$ : 高炉ガスのカロリー值, $\mathrm{kcal} / \mathrm{m}^{3}$

$\mathrm{t} ： 1$ 周期におけする通風時間に対する加熱特間の比 $\mathrm{h} / \mathrm{h}$

次に Hochofenbetrieb に示されている方法により次 式を適用する.

$$
\begin{aligned}
& \theta_{2}=\theta_{1}-\left(\theta_{1}-\theta_{1}{ }^{\prime}\right) \cdot \mathrm{w}^{\prime} / \mathrm{w} \cdot(1-\mathrm{f}) \\
& \theta_{2}{ }^{\prime}=\theta_{1}-\left(\theta_{1}-\theta_{1}{ }^{\prime}\right) \cdot \mathrm{f} \ldots \ldots \ldots \ldots \ldots \ldots \ldots
\end{aligned}
$$

$\theta_{1}:$ 燃焼ガスの最初の温度, ${ }^{\circ} \mathrm{C}$

$\theta_{2}:$ 燃焼ガスの最後の温度, ${ }^{\circ} \mathrm{C}$

$\mathrm{C}$ : 燃焼ガスの比熱, $\mathrm{kcal} / \mathrm{m}^{3} /{ }^{\circ} \mathrm{C}$

$\mathrm{V}:$ 燃焼ガス量, $\mathrm{m}^{3} /$ cycle

燃焼ガス熱当量 : $\mathrm{w}=\mathrm{V} \cdot \mathrm{C}$ 熱風熱当量 $\mathrm{w}^{\prime}=\mathrm{V}^{\prime} \mathrm{C}^{\prime}$

また上式の $\mathrm{f}$ は $\mathrm{f}=\left(1-\mathrm{w} / \mathrm{w}^{\prime}\right) /\left(1-\mathrm{w} / \mathrm{w}^{\prime} \cdot \mathrm{e}^{m}\right) \cdots(\mathrm{a})$

また式中 $\mathrm{m}$ は $\mathrm{m}=\mathrm{K} \cdot \mathrm{s} / \mathrm{w} \cdot\left(1-\mathrm{w} / \mathrm{w}^{\prime}\right)$

$\mathrm{K}:$ ギッターの熱伝達係数, $\mathrm{kcal} /{ }^{\circ} \mathrm{C} \cdot \mathrm{m}^{2} \cdot \mathrm{cycle}$

$\mathrm{S}$ : 所要加熱面積, $\mathrm{m}^{2} /$ stove

次に $(1)-(2)$

$\theta_{2}-\theta_{2}{ }^{\prime}=\mathrm{f}\left(\theta_{1}-6_{1}{ }^{\prime}\right)\left(1+\mathrm{w}^{\prime} / \mathrm{w}\right)-\mathrm{w}^{\prime} / \mathrm{w} \cdot\left(\theta_{1}-\theta_{1}{ }^{\prime}\right)$

したがつて $\mathrm{f}=\left\{\left(\theta_{2}-\theta_{2}{ }^{\prime}\right)+\mathrm{w}^{\prime} / \mathrm{w} \cdot\left(\theta_{1}-\theta_{1}{ }^{\prime}\right)\right\} /$

$$
\left(\theta_{1}-\theta_{1}{ }^{\prime}\right) \cdot\left(1+\mathrm{w}^{\prime} / \mathrm{w}\right)
$$

上式を(a)に代入すると

$$
\begin{aligned}
& \left\{\left(\theta_{2}-\theta_{2}{ }^{\prime}\right)+\mathrm{w}^{\prime} / \mathrm{w} \cdot\left(\theta_{1}-\epsilon_{1}{ }^{\prime}\right)\right\} /\left(\theta_{1}-{ }_{1}{ }^{\prime}\right) \cdot\left(1+\mathrm{w}^{\prime} / \mathrm{w} \cdot\right) \\
& \quad=\left(1-\mathrm{w} / \mathrm{w}^{\prime}\right) /\left(1-\mathrm{w} / \mathrm{w}^{\prime} \cdot \mathrm{e}^{m}\right) \\
& \mathrm{e}^{m}=\left\{\left(\theta_{2}-\theta_{2}{ }^{\prime}\right)+\mathrm{w}^{\prime} / \mathrm{w}\left(\theta_{1}-\theta_{1}{ }^{\prime}\right)-\left(1-\mathrm{w} / \mathrm{w}^{\prime}\right)\left(\theta_{1}-6_{1}{ }^{\prime}\right)\right.
\end{aligned}
$$

$$
\left.\left(1+\mathrm{w}^{\prime} / \mathrm{w}\right)\right\} /\left\{\mathrm{w} / \mathrm{w}_{1}\left(\theta_{2}-\theta_{2}{ }^{\prime}\right)+\left(\theta_{1}-\theta_{1}{ }^{\prime}\right)\right\}
$$

これを解いて

$$
\begin{aligned}
\mathrm{m} & =2 \cdot 3026 \log \left[\left\{\left(\theta_{2}-\theta_{2}{ }^{\prime}\right)+\mathrm{w}^{\prime} / \mathrm{w}\left(\theta_{1}-\theta_{1}{ }^{\prime}\right)-\right.\right. \\
& \left.\left(1-\mathrm{w} / \mathrm{w}^{\prime}\right)\left(\theta_{1}-\theta_{1}{ }^{\prime}\right)\left(1+\mathrm{w}^{\prime} / \mathrm{w}\right)\right\} /\left\{\mathrm{w} / \mathrm{w}^{\prime}\left(\theta_{2}-\theta_{2}{ }^{\prime}\right)\right. \\
& \left.\left.+\left(\theta_{1}-\theta_{1}{ }^{\prime}\right)\right\}\right]
\end{aligned}
$$

上式と ( b ) より加熱面積 S は次式により与えられる. $\left.\mathrm{S}=2 \cdot 3026 \mathrm{w} / \mathrm{K} \cdot\left(\mathrm{w} / \mathrm{w}^{\prime}-1\right) \cdot \log [\} \theta_{2}-\theta_{2}{ }^{\prime}\right)+\mathrm{w}^{\prime} / \mathrm{w}$

$$
\left.\left(\theta_{1}-\theta_{1}{ }^{\prime}\right)-\left(1-\mathrm{w} / \mathrm{w}^{\prime}\right)\left(\theta_{1}-\theta_{1}{ }^{\prime}\right)\left(1+\mathrm{w}^{\prime} / \mathrm{w}\right)\right\} / .
$$$$
\left.\left\{\mathrm{w} / \mathrm{w}^{\prime}\left(\theta_{2}-\theta_{2}{ }^{\prime}\right)+\left(\theta_{1}-\theta_{1}{ }^{\prime}\right)\right\}\right]
$$

蓄熱室烟瓦形状は伝熱工学より最良の形状を決定すべ きであると思われるが，現状においては熱風炉の通気抵 抗, 通風速度, 煉瓦の熱容量および耐圧強度などについ て過去の資料に基づき検討改善して形状を定め, 熱层達 係数 : $\mathrm{K} \mathrm{kcal} /{ }^{\circ} \mathrm{C} \mathrm{m}^{2} \mathrm{cycle}$ を計算する場合が多いようで ある.この場合の熱伝達係数の解法については種々の計 算法が報告されている，計算の原理は燃焼期においては 高温度の 3 原子分子 $\left(\mathrm{CO}_{2}\right)$ のガス組成が高いためガス から固体への伝熱は輻射と対流が作用し，通風期に拈け る固体から空気への伝熱は対流によるとして計算式を導 出している. 熱伝達係数を求めることにより(3) 式より 蓄熱室煉瓦積の加熱面積が計算できる．また蓄熱室煉瓦 形状と質量より煉瓦重量が計算できる.

\section{4·4·2 加熱面積ならびに蓄熱室煉瓦形状}

熱風炉の加熱面積は通常蓄熱室煉瓦積の表面積で表わ される. 次に昭和 31 年 4 月〜36年 7 月の期間に打いて改 修または新設された 3 基操業の熱風炉を対象として, 高 炉16基より高炉内容積と熱風炉加熱面積の関係を調査し て図 4.9 に示す.この期間においては, 高炉操業技術の

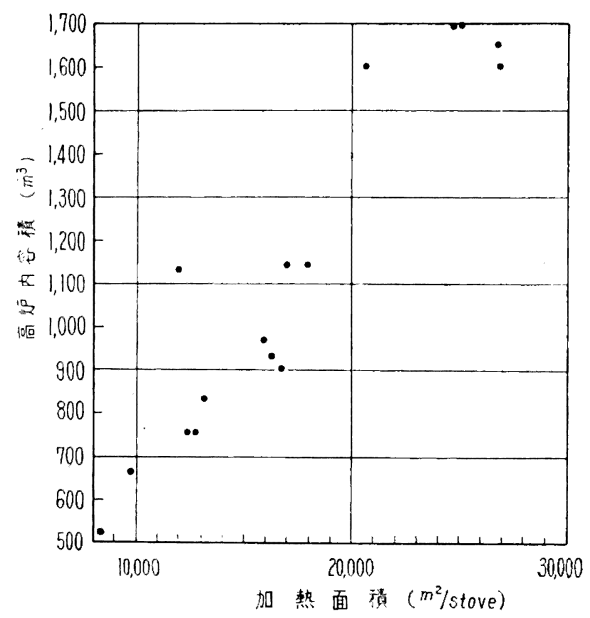

图 4 •9 高炉内容皘と䔄熱室加熱面積との関係 
発展は極めて急速であり，大巾な設計条件の相違がある と思われる. 先の図 4.9 に示した加熱面䅡は高㭁ガスの カロリ一值 $800 \mathrm{kcal} / \mathrm{m}^{3}$ とし, 高邩出銑比 $1.5 \mathrm{t} / \mathrm{m}^{3}$ 程 度までの能力に対して熱風温度 $1,000^{\circ} \mathrm{C}$ 内外の熱負荷に 応じうるすのと思われる. しかし今後, 高炉ガスの力口 リ一値がさらに低下するので然焼がス火炎温度もしたが つて低下する，熱風温度が $1,000^{\circ} \mathrm{C}$ をえるようになる と排気温度が上年して熱効率が低下する照念が生ずる. これの対策として図 4.9 の傾向以上に加熱面積が拡大さ れる傾向にあり，その一例として昭和36年 9 月に建設さ れた内容積 1,243 $\mathrm{m}^{3}$ の高炬は加熱面積を $29,000 \mathrm{~m}^{2}$ ま で拡大した熱風炉を装備している。

蓄熱室煉瓦の通気孔の形状は熱工学的な過程に影響を 与えないといわれている(富士・室闌).すなわち, 空隙 比と通気孔の水力直径が等しい場合には形状が相違して も蓄熱室単位容積当たりの加熱面皘は等しく, また加熱 面栍 $\mathrm{m}^{2}$ 当りの煉瓦重量も等しくなる. このため通気孔 の形状選択上問題となることは煉瓦構造の強さ, 煉瓦の 有効利用度扣よび淿瓦製作上の難易などである。従来か ら使用されていた格子形蓄熱室煉瓦積は現在でも数多く 使用されているが老化により蓄熱室外周部煉瓦積が変形 または破損して通気孔が閉塞する場合が多いので，近年 はブロック積構造が使用される傾向にある.ブロック積 は構造が安定し, 各ブロックに側通路をもち一部の通気 孔が閉塞したときも蓄熱室煉瓦利用効率低下を最少にす る利点がある. また特に加熱面積および煉瓦重量の增大 か要求され通気孔の断面䅡を小さくして孔の数を增加す ることが必要なときに,ブロック煉瓦は構造的に安定で 有利である.ブロック煉瓦の通気孔の形状は製作の容易 な円形が比較的有效利用度も高いので一般的に使用され る傾向となつた：また熱風炉蓄熱室は高さによつて層状 に分割して通気孔の形状を変える多層式と, 全高に対し て同一の通気孔から成立つている単層式とがある. 一般 に蓄熱室の上部と下部では通過する気体の温度が異な り, したがつて流速も変化する. 流速の速い上部では圧 力損失が大きく下部においては圧力損失が少ない、また 上部はダスト付着により通気孔の断面積が縮少する傾向 にあることを考虑しなけ机ばならない，一方熱効率を向 上するためには, 落熱室の熱容量を大にして排気温度を 低くしなければならない。このために必要にして充分な 加熱面積と鈥瓦重量をもたねばならないことは勿論であ るが, 各レベルについて考えれば, 高温部の蓄熱室上部 は煉瓦重量に重点を扣き低温度の下部では加熱面積を大 にすることが望ましい，現在稼動中の熱風炉の大部分は
多層式で単層式のものは極めて少ないままた多層式の場 合, 2 層式あるいは 3 層式が採用されている.

\section{$4 \cdot 4 \cdot 3$ 耐火煉瓦および煉瓦受金物}

過去の熱風邩は，高温部すなわち燃焼室ドーム，蓄熱 室上部とそれ以外の部分とに分け SK 32 打よび SK 31 のシャモット質煉瓦が区分して使用されていた．その後 高温部に比較的アルミナ組成の高い耐火度, 耐スポール 性ともにすぐれた煉瓦を使用するようになつた。

最近にいたり高炉の高温送風に応じて熱風炉の熱負荷 はますます增加し、このため $50 \% \mathrm{Al}_{2} \mathrm{O}_{3}$ 以上の高アルミ ナ質耐火煉瓦が燃焼室, ドーム, および上部蓄熱室に使 用されるようになり，ドーム温度限界は1, 250〜 1, 300 $\mathrm{C}$ 程度にまで高めることが可能となつた。また，鉄皮と耐 火煉瓦の間腺部はイソライト煉瓦, 鉣㳯綿, およびシリ カボードなどにより断熱㬝を強化した・また煉瓦受けは 単重 $50 \mathrm{~kg}$ 程度の大煉瓦を使用するものが多かつたが, このような材質の煉瓦受けは長期使用中, 荷重および熱 により曲げ応力を受け, 大部分の煉瓦受けが中央部に亀 裂を生した.このため煉瓦受けは耐熱鋳鉄製のものと变 わり，同材質の支柱を使用するようになつた：この金物 は $400^{\circ} \mathrm{C}$ 程度までは変形または軞裂を生ずることがなく 蓄熱室煉瓦積に安定した支持を与えることが可能となつ た.

\subsection{4 パーナーおよび弁関係設備}

10年前の熱風炉バーナーは自然通風バーナーで, 高炉 ガスと燃焼用空気との接触面積を多くして燃焼させる形 式，たとえば菊形バーナーなどが使われた。また通風期 においてはバーナー設備が炬から完全に分離される開放 式が多く使用され，したがつて炉の切替作業はすべて手 動操作により行なわれていた。しかし熱風炉の熱容量の

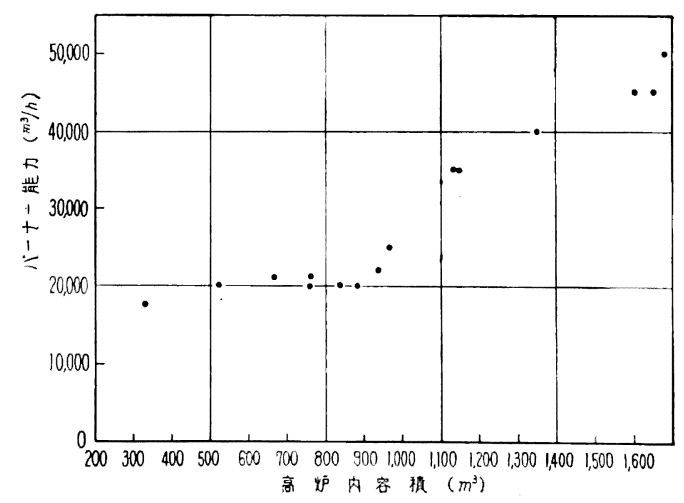

図4・10高炉内容程と熱風炬バーナー容量の現況 
增加と，制御技術の発展により現在では強制通風による 密閉式バーナーが多く採用され広く使用されるよ5にな つた。また弁は自動切替に適切な型式が採用されてい る. 図4・10に熱風㭁 3 基操業を行なつている高炬15基の 高㚸内容皘と最大バーナー容量の現況を示した。

熱風如の切替に必要な弁は遮断弁, 煙道弁, 送風弁, ガス弁，熱風升，であつて炣によつては充圧弁拈よび混 合泠風升なよ゙を有するものもある，通常熱風弁は水冷さ れているが，その他の弁は一般に水冷しない，大型熱風 炬の煙道升は加熱期において均一に蓄熱室煉瓦を加熱す るため 2 個設置されているものが多く、また送風弁およ び煙道弁は燃焼・送風の切替時に炉内圧力を調整して弁 の作動に圧力負荷を加えないために小弁を設けるように なつた・次に然焼制御にはガス・バタフライ升, 空気ハ タフライ升, 熱風温度制御には熱風温度調節バタフライ 弁, 冷風バタフライ弁などがある.この他休風時におけ る高炉から熱風炉への逆流がスを遮断するために，熱風 本管に休風升を設けることがあり，ガス管にはガス遮断 弁などがある.これらの弁は手動操作，遠隔操作拉よび 自動制御などの操作法を組合せた設備になつている.

熱風灯の切替に才いて燃焼より送風に移行する場合, 前述の泠風小弁により充王を行なつても熱風圧力は変動 して高灯操業条件に変化を与えることになり, 特に高炉 操業状態の順調でない場合は熱風圧力の変動によりスリ ップ、胡などを誘発することが多かつた。このため近年 熱風圧力の変化を防ぐ目的で別に充王機を設置し, 高炬 々況に変動を与えることなく円滑に炬切替を行なつてい る例がある。

\section{$4 \cdot 4 \cdot 5$ 熱風炉の自動制御}

現在の熱風炉設備において実際に使用されている自動 制䘖は次に示すものである。

（1）熱風温度自動制御

（2）燃筶自動制御
a . $\dot{ト}-么$ 最高温度調節
b. 空然比率調節
c. 燃料ガス流量調節

（3）、自動切替

通常これらはいずれも計器室からの遠隔操作であるが 現場手動操作に切替使用が可能である. 熱風温度の自動 制御は熱風炉通過風量と泠風混合管通過風量の混合率を 制御して熱風本管における指定温度に調節する操作であ る.すなわち，熱風炬を送風に切替えた直後においては 熱風出口温度は最高であり, 時間の経過とともに温度が
降下する，このため冷風混合管の冷風混合バタフライ弁 を送風の始めた開度を最大にして冷風混合量を最も多く し, 熱風出口温度の降下に従つて開度を締め, 指定熱風 温度に調節する機䊗である.この場合, 熱風炉の泠風: タフライ弁の操作をも操作回路に組入れて冷風混合バ フライ弁とともに熱風炉通過風量を自動制御している炉 もあるが, 現状に拈いては熱風温度が高くなり熱風炉通 過風量が増加したため, 余り必要とは考えられない, 次 に自動然焼制御方式についてであるが，先ず次の設定を 行な 5 .

（1）あらかじめ作成された熱風温度ならびに送風量か ら然料ガス量を設定する.

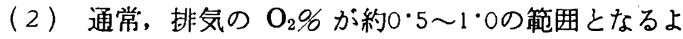
5に, 燃料ガス成分から燃焼用空気の過剩率を計算し て空燃比率を設定する.

（3）ドーム最高温度を設定する. 熱風炉の燃焼期にお いてドーム温度は燃焼経過時間とともに上界する.そ してドーム温度が最高設定值に到達した場合, 燃料ガ ス量を変更することなく燃烧火炎ガス温度を下げるた め空気過剩率を增加するよ5空燃比率調節器が自動的 に作用するように設計されている.

熱風炉を送風から然焼に切替えた場合，遮断弁が開く と同時にファンが起動し空気バタフライ弁がある開度に まで開き，空気が一定量熱風炉に導入されてからガス弁 が開き，次にガスハタフライ弁が燃料ガス設定量まで開 くように設備されたものが多い.

炬切替作業の手動操作は切替に長時間を要するため加 熱時間が短縮され，また誤操作による危険も多かつた。 しかし現在の熱風炉は大部分が自動または半自動による 切替作業を行ない，切替時間を短縮し，また誤操作の䊝 念も解消した.

一般に熱風灯の自動切替は半自動方式を指す場合が多 い半自動方式は送風，燃焼および休止の指示を切替え ることにより，以後は自動的に作動する方式のことであ る. 全自動方式は熱風出口温度と熱風温度の差, 通風時 間, 排気温度または冷風混合弁開度などを検出し, 設定 值に達すると切替指令を出すもので完全な自動方式とな つたものである・しかし現在においては半自動方式が自 動切替と称される場合が多く，いまたこのような全自動 切替設備は広く採用されていない。

熱風炉の自動, 半自動の切替のための駆動々力は, 電 気式と空気式または併用式などがある，数年前までは空 気式のものが多く採用されていたが，近年にいたり電気 式も使用されるよ5になつた。電気式はインターロック 
ならびに自動化が容易であり，また機器の故障も少なく なつたためと考えられる.

以上のよ5に熱風灯の自動化は過去数年間に著しい進 歩を示した。

\section{4·4·6 熱風炬設備に対する今後の課題}

高炉は将来大型化に向つて発展し、これに伴なつて送 風量も增大しまたコークス節減のため高温度の熱風を必 要とする傾向は益々強くなるであろう.さらに重油など の然料を羽ロから吹込むためにも高温度の熱風を必要と することは論をまたない。このため将来の熱風炉の設計 については検討を要する重要な課題が多い. 次に問題点 およびその対策について示す.

（1）耐火物の耐熱性の向上

シリマナイト亲, 高アルミナ系および珪石煉瓦など の使用

（2）燃焼ガス火炎温度の上升

a. 燃焼用空気および然料ガスの予熱

b.コークス炉ガスあるいは他の高発熱量然料と高 炬ガスとの混合

c. 燃赎用空気の酸素富化

（3）加熱面䅡の增大

（4）弁設備の耐熱性の向上と大型化

(5) 高王操業に対する対策

（6）独立した燃焼室の設計

など考えられるが,これらの問題点は高炬操業技術の進 展と密接な関連を保ちながら, 検討を必要とする.

\section{$4 \cdot 5$ ガス清浄設備}

近年, 高炉原料の性状は著しく改善され, この結果, 炬内にお!子るガス固体間の反応は增進し, 暁結鉱の還元 性についても顕著に改善されたこのため. CO ガスの 炉内利用度は大幅に上年し, 炬頂ガス中の $\mathrm{CO}$ 成分は著 しく低下し $\mathrm{CO} / \mathrm{CO}_{2}$ が1に近い高炉も出現するよ5に なつた・したがつて高炉ガスは 700〜 $850 \mathrm{kcal} / \mathrm{m}^{3}$ の箸 囲の低カロリー然料となつたが，なお熱風炉、コークス 炉，加熱焙およびボイラーなどの熱源として重要な役割 を果たしている．また銑鉄 $\mathrm{t}$ 当り発生ガス量はコークス 比の低下により，1,800〜2,000 $\mathrm{m}^{3} / \mathrm{t} \cdot$ pig まで減少した. 焼結鉱の強度の向上, 装入粉率の激減などにより, 高炉 ガス中のガス灰量は著しく減少し, 通常 $5 \sim 30 \mathrm{~g} / \mathrm{m}^{3}$ 程 度である.この結果, 一般の乾式除鹰器において捕集さ れるガス灰量は極めて少なくなつている. しかし高炉ガ ス使用部門のハーナー, バルブ類の污損防止のため, ガ
ス清浄の重要なことはここで述べるまでもない.また熱 風炉の熱負荷の增大により, 淿瓦の耐火度の低下と目詰 り防止の見地からもガス清浄の重要性はさらに強くなつ た. 最近にいたり高炉燃料としての重油吹込がガス中に カーボン・ブラックを增加させることがあり，この対策 としてガス清浄設供の改良に関する検討が必要となつて きた。

\section{$4 \cdot 5 \cdot 1$ ガス清浄設備}

高炉ガス中のガス灰は主にコークス鉄鉱石の微粉から 成り, その化学成分は炭素, 酸化鉄, が主体であり少量 の酸化亜鉛を含さのが普通である.したがつて粒子の密 度の相違は極めて大であり, その粒子は数 $\mathrm{mm}$ の粗大粒 子のものから $1 \mu$ 以下の粒子にいたる広範囲の粒度分布 をもつている.このため清浄効率を保証するには機能の 異なるガス灰捕集器を適切に組合せ配列した一連の設備 を使用するのが経済的であり，また能率的である. 比較 的粗い粒子の捕集を目的としたものを一次清浄装置, 微 粒子のものを最終的に捕集するものを二次清浄装置と一 般にいわれている. 高炉ガス清浄設備は機械的清浄方法 と電気的清浄方法に大別できる. 機械的清浄方式による 設備としては除鷹器, サイクロン, スクラバーおよびタ イゼン・洗浄機などがあり，電気的清浄方法による設備 としては乾式電気集朢器と湿式電気集虞器がある.この 万ち近年においては清浄効率の点から主として湿式集鷹 器が使用される傾向にある. 現在適用されている高炬ガ ス清浄系列は二次清浄装置の種別により, 次の 2 系列に 分類できる.

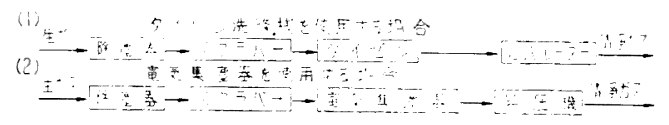

除磨器とスクラバー間にサイクロンを設備している製 鉄所もある.スクラパーとしてはハードルワッシャ一, スプレータワーおよびヘンンュリースクラバーなどが使 用されているまた界圧機を省く場合も多くなつた。す なわち上記各系列は粗大粒子の捕集を対象とした集塺器 から順次微細粒子のガス灰を捕集して，ガス清浄度を高 めるよ5に配置されている。一般に電気集麼器を使用す るものがガス清浄度が高いタイゼンは翼車の回転によ る年圧能力を有するため, 普通, 升圧機を設㯰しない。 またタイゼン出口清浄ガスの水分が高いためセパレータ 一を通してガス中の水分を除去する一次清浄装置で捕集 されたガス灰はその物理的ならびに化学的性状から暁結 原料として利用され，二次湿式清浄装置よりの排水はシ 
ックナーおよびその他の装置により処理されることが多 い. 表 $4 \cdot 2$ に各社の二次清浄設備の概況を示す.

表 $4 \cdot 2$ 各社二次清浄設備の概況

\begin{tabular}{|c|c|c|c|}
\hline 会社名 & 高 炉 名 & 二次 & $\begin{array}{c}\text { 容 } \\
\text { (1 基 } \\
\end{array}$ \\
\hline \multicolumn{2}{|c|}{ 八幡戸畑No. 3} & \multirow{2}{*}{$\begin{array}{c}\text { ルルギー式 (ペンチ } \\
\text { ユリオン型) } \\
\text { " }\end{array}$} & $100,000 \mathrm{~m}^{3} / \mathrm{h}$ \\
\hline 日新 呉 & No. 1 & & $70,000 \mathrm{~m}^{3} / \mathrm{h}$ \\
\hline 士室闌 & No. 1 & $\prime \prime$ & $100,000 \mathrm{~m}^{3} / \mathrm{h}$ \\
\hline$\prime \prime$ & No. 4 & $\prime \prime$ & "l \\
\hline 八幡戸畑 & No. 1,2 & $\begin{array}{c}\prime(\text { スプレータ } \\
\text { ワー型 })\end{array}$ & $50,000 \mathrm{~m}^{3} / \mathrm{h}$ \\
\hline & $\mathrm{N}$ & ウェスタン式 & $60,000 \mathrm{~m}^{3} / \mathrm{h}$ \\
\hline 芦 & No. 1 & $\prime \prime$ & $30,000 \mathrm{~m}^{3} / \mathrm{h}$ \\
\hline " & No. 2 & $\prime \prime$ & $42,500 \mathrm{~m}^{3} / \mathrm{h}$ \\
\hline 石 & No. 1 & $\prime \prime$ & $60,000 \mathrm{~m}^{3} / \mathrm{h}$ \\
\hline 山 & No. 1,2 & 乾式電気集歴器 & \\
\hline 八嶓洞岡 & No. $1,2,3,4$ & $\prime \prime$ & $300,000 \mathrm{~m}^{3} / \mathrm{h}$ \\
\hline 鉄 & No. 1,2 & $\begin{array}{l}\text { フラクト, ファプリ } \\
\text { ケン FAV 型 }\end{array}$ & $170,000 \mathrm{~m}^{3} / \mathrm{h}$ \\
\hline 神鋼神戸 & No. 1 & タイゼン & $60,000 \mathrm{~m}^{3} / \mathrm{h}$ \\
\hline 鋼管川崎 & No. 2, 3, 4, 5 & $"$ & $\left\{\begin{array}{l}90,000 \mathrm{~m}^{3} / \mathrm{h} \\
60,000 \mathrm{~m}^{3} / \mathrm{h}\end{array}\right.$ \\
\hline " 鶴見 & No. 2 & $" \prime$ & $50,000 \mathrm{~m}^{3} / \mathrm{h}$ \\
\hline & No. 1, 2 & $" \prime$ & $\prime \prime$ \\
\hline & No. 5 & エレック & $25,000 \mathrm{~m}^{3} / \mathrm{h}$ \\
\hline
\end{tabular}

\section{5·2 弁ならびにガス圧制御設備の進歩}

従来, 高炉ガス管系において使用されていたガス遮断 弁は主として水封弁である. 水封弁は水封によつてガス 通路を閉塞するため, ガス漏れは全くないが水封に時間 を要するため近年においては主としてゴッグル弁が使用 されるようになつた・ゴッグル弁は弁の開閉時, 少量の ガス漏れはあるが，短時間に弁を開閉する利点がある. ゴッグル弁の作動は現場手動または電動などによつて行 なわれている.また従来のガス圧調節は各ガス管部に設 けられた個々の現場手動バタフライ弁およびアスカニア 式自動ガス圧調節器により管理されていたが, 近年, 計 測技術の進歩とともにガス圧制御室による中央管理方式 に変わりつつある. 特に余剩ガスの処理に対しては高炉 々頂ブリーダーあるいはガス管のブリーダーを現場手動 により開放して放散していたものが近年においてはガス 管に設けられた自動ガス放散点火装置により自動的に放 散, 点火される場合もある. 高圧操業においては炉頂圧 力を高めるため圧力調整弁を設ける.

\section{$4 \cdot 5 \cdot 3$ 集塵効率の現況}

前述のよ5に高炉ガス利用部門は清浄ガスのガス灰含 有量の少ないことが望ましいが，実際には経済的見地か
ら許容できる含摩量を決定してそれにしたがい設計なら びに運転を行な 5 べきである. 許容含塺量は用途によつ て異なるが, 普通 $0.005 \sim 0.02 \mathrm{~g} / \mathrm{m}^{3}$ とされている. 清 浄ガスの含麼量を連続的に検出し, 監視するためカプ, グラフまたは光電管式検麼計を設置することもあるが, 精度を要求する場合は一般にガス中のガス灰を抽出し測 定する定量法による検定が行なわれている・集磨効率は 清浄器前後の含匳量を測定することにより次式で表わさ れる・すなわち

集魔効密 $(\%): \quad \eta=\left(1-\mathrm{w}_{2} / \mathrm{w}_{1}\right) \times 100$

ただし $\mathrm{W}_{1}$ : 清浄器前のガス中含麼量 $\left(\mathrm{g} / \mathrm{m}^{3}\right)$ $\mathrm{w}_{2}$ : 清浄器後のガス中含塵量 $\left(\mathrm{g} / \mathrm{m}^{3}\right)$

一般に清浄ガスの含麼量は最終的に二次清浄設備の集 麼能力により大きく影響される. 通常, 清浄度はタイゼ ンより乾式電気集㖸器, また乾式電気集䵇器より湿式電 気集麼器が優れているといわれている表 4.3 に各社の集 䵇成績を示す.（第14回部会）

表 $4 \cdot 3$ 各社集塺成績

\begin{tabular}{|c|c|c|c|c|c|}
\hline \multirow{2}{*}{ 会社名 } & \multirow{2}{*}{$\begin{array}{l}\text { 二次清浄 } \\
\text { 設 備 名 }\end{array}$} & \multicolumn{4}{|c|}{ 含 麼 量 $\left(\mathrm{g} / \mathrm{m}^{3}\right)$} \\
\hline & & \begin{tabular}{|l|} 
除栕器 \\
口
\end{tabular} & $\begin{array}{l}\text { 除塵器 } \\
\text { 出口 }\end{array}$ & $\left|\begin{array}{l}\text { スクラバ } \\
- \text { 出口 }\end{array}\right|$ & 清浄ガス \\
\hline 川鉄千葉 & $\begin{array}{l}\text { ルギ-式 } \\
\text { 湿式 E.P }\end{array}$ & - & 12 & 0.8 以下 & 0.003 \\
\hline 富士金石 & $\begin{array}{r}\text { ウェタン式 } \\
\text { 湿式 E.P }\end{array}$ & $20 \sim 30$ & $5 \sim 8$ & 0.6 & .006 \\
\hline 住金小倉 & $" \prime$ & $20 \sim 50$ & $10 \sim 20$ & $1 \cdot 0 \sim 1 \cdot 5$ & 0.005 \\
\hline 八 & 乾·湿式E.P & 10 & & $50.6 \sim 0.8$ & 0.008 \\
\hline 中 & 乾式 E.P & 一 & - & 2 & 0.004 \\
\hline 富士室闌 & タイゼン & $8 \cdot 5$ & $3 \cdot 5$ & $0 \cdot 45 !$ & 0.025 \\
\hline 鋼管川崎 & $\prime \prime$ & 15 & 6 & 0.6 & 0.02 \\
\hline " 鶴見 & $\prime \prime$ & 12 & 5 & 0.8 & 0.03 \\
\hline 尼鉄 & $" \prime$ & -15 & $2 \sim 5$ & $0 \cdot 5 \sim 1 \cdot 5$ & $\begin{array}{l}0.02 \\
\sim 0.04\end{array}$ \\
\hline
\end{tabular}

E.P : 電気集塺器

\section{4·5·4 ガス清浄装置の種類}

\section{(1) 乾式除䴟器}

ガス中の粗いガス灰を除去するため, 乾式除麼器が高 炉の直後に設置される，発生ガス量は各高炉により異な るためその大きさも異なる. 図4・11に乾式除塵器の概要 を示す.

高炬ガスは上部より流入し円筒内でガス流速は低下し ガス中のガス灰が下部に落ちる・除塺されたガスは内管 と外管の間隙を通過し，また下部にたまつたガス灰は定 期的に除去する・ガス灰取出口にパッグミルを設備する とガスの噴出を防止しながら容易にガス灰を排出するこ 


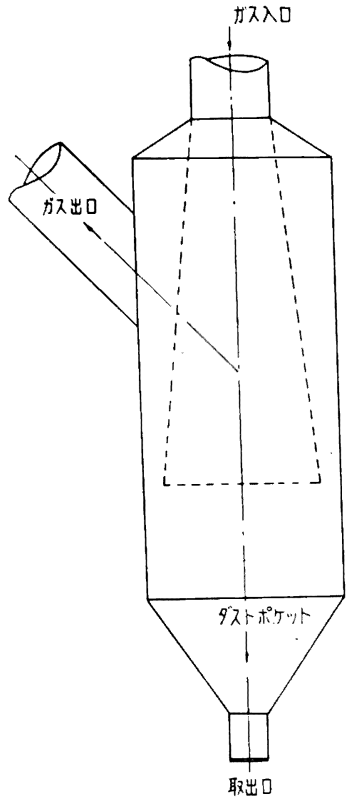

図4.11乾式除塵器

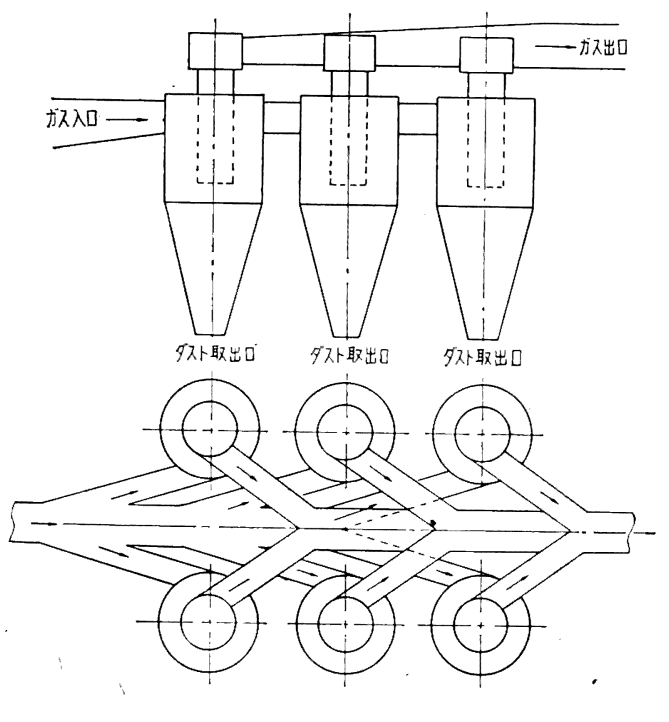

図4・12 サイクロン

とができる. 除䴢器の胴径はガス流速を $1 \mathrm{~m} / \mathrm{s}$ 前後にな るように設計しているものが多い。

(2) サイクロン

乾式除嘕器で捕集されなかつた比較的に細かいガス灰 を捕集するためにサイクロンを設けることがある. 図 4・12にサイクロンの概要を示す. また表 $4 \cdot 4$ に乾式除麼 器とサイクロンのガス灰の粒度分布を示す.
表 $4 \cdot 3$ ガス灰粒度分布の相違

\begin{tabular}{|c|c|c|c|c|c|c|c|}
\hline 粒 度 & -200 & $\begin{array}{r}200 \sim \\
150\end{array}$ & $\begin{array}{r}150 \sim \\
100\end{array}$ & $\begin{array}{r}100 \sim \\
80\end{array}$ & $80 \sim 60$ & $\int^{60} \sim$ & +42 \\
\hline & $\%$ & $\%$ & $\%$ & $\%$ & $\%$ & $\%$ & $\%$ \\
\hline 除＼cjkstart塵＼cjkstart器 & 13 & 10 & 30 & 13 & 12 & 18 & 4 \\
\hline サイクロン & 83 & 10 & 5 & 2 & - & 一 & - \\
\hline
\end{tabular}

サイクロンは事後の清浄器の負荷を軽减する利点があ るが，反面，ガス圧損失を生ずる欠点がある.

(3) スクラパー

a. ペンチュリー・スクラバー

ガス管をベンチュリータイプに絞り，ガスを噴出 膨張させ，同時に散水して温度降下を効果的にする とともに集鷹効率を向上する装置である・図 $4 \cdot 13$ にペンチュリー・スクラバーを示す.

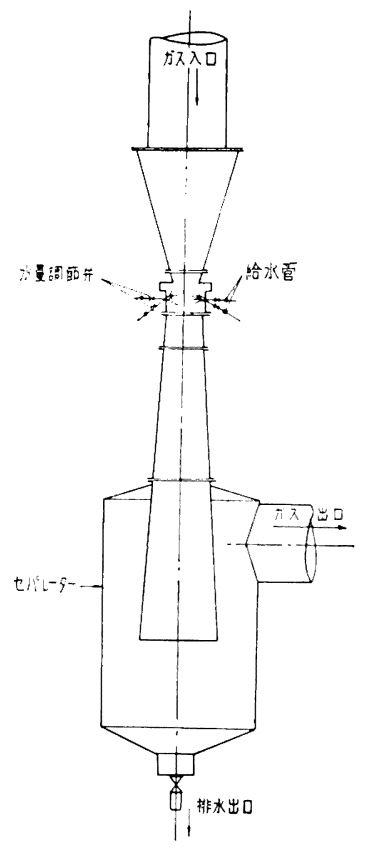

図4.13 ペンチュリー・スクラパー

b. プレ・クーラー

ガスの温度を低下させ同時に除塺を行ならためプ レ・クーラーを設置する.内部にハードルを組入れ 上部より散水するものをハードル・ワッシャーとい う.しかしハードル・ワッシャーはガスの通過に抵 抗を与える不利があるのでスプレーノズルの改良に ともない，次第に使用さなくなつた．ガスの流入方 向は上部より下部に流れるものと下部より上部に流 れる 2 方式があるがいずれも除麼効率は70〜80\%で 


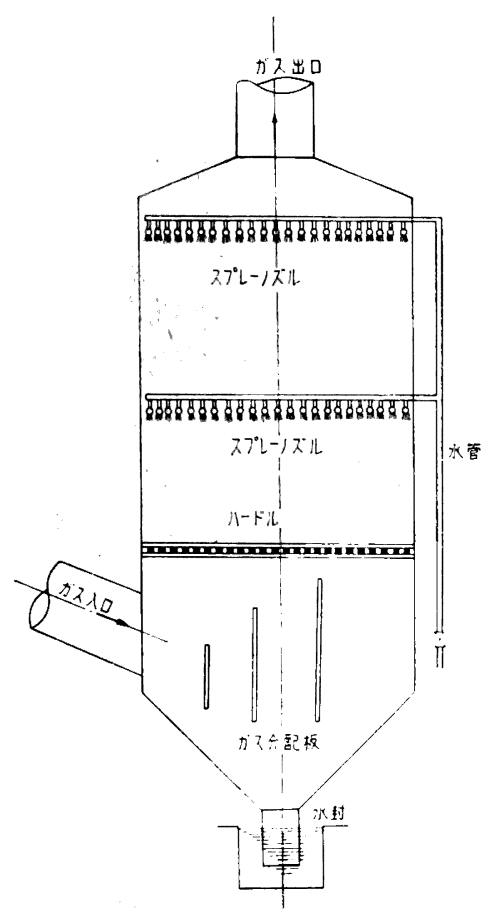

図4.14 プレ・クーラー

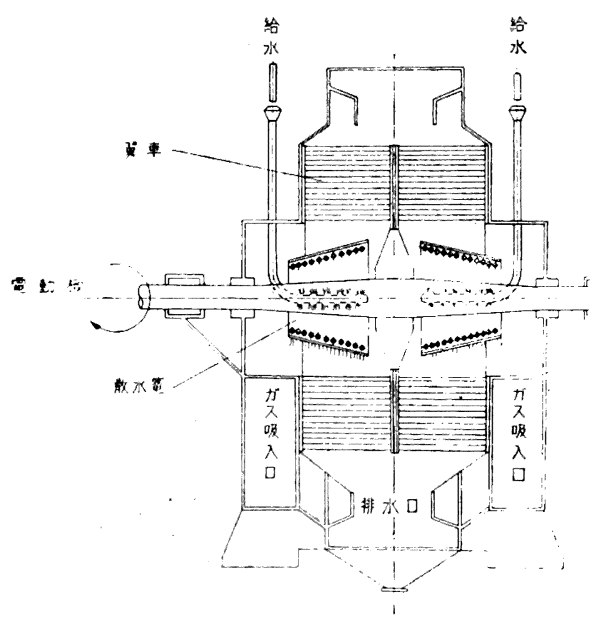

図4.15タイゼン洗浄機

ある. 图 $4 \cdot 14$ にプレ・クーラーの概略を示す.

(4) 回転式ガス清浄機

二次清浄装置として回転式ガス洗浄機がある.こ れの代表的なものはタイゼン洗浄機である. 図4・15 にタイゼンの概要を示す. 軸方向より流入するガスに軸 に固定させた籠を回転することにより水滴を飛散させ。

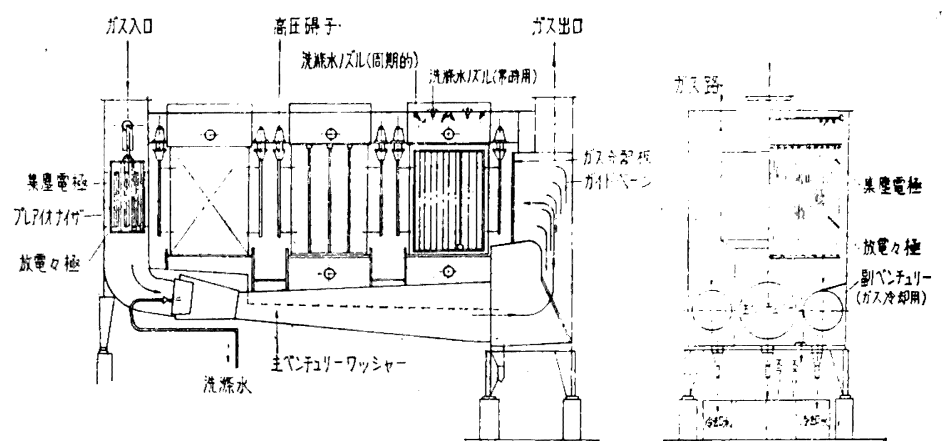

図4.16ルルギ一式集塵器

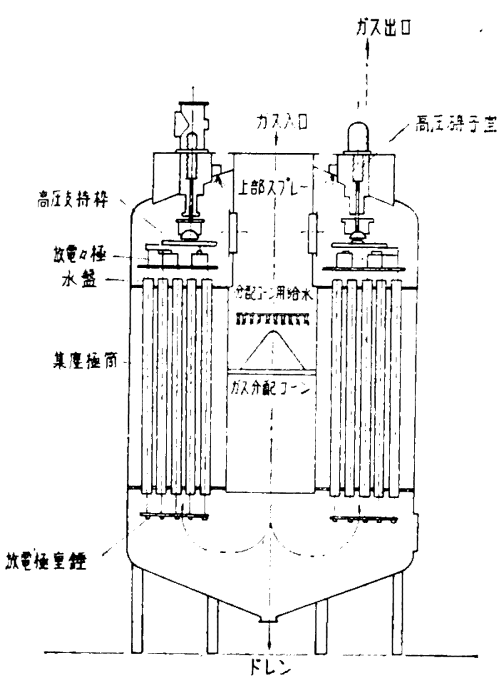

図4・17 ウェスタン式電気集塵器

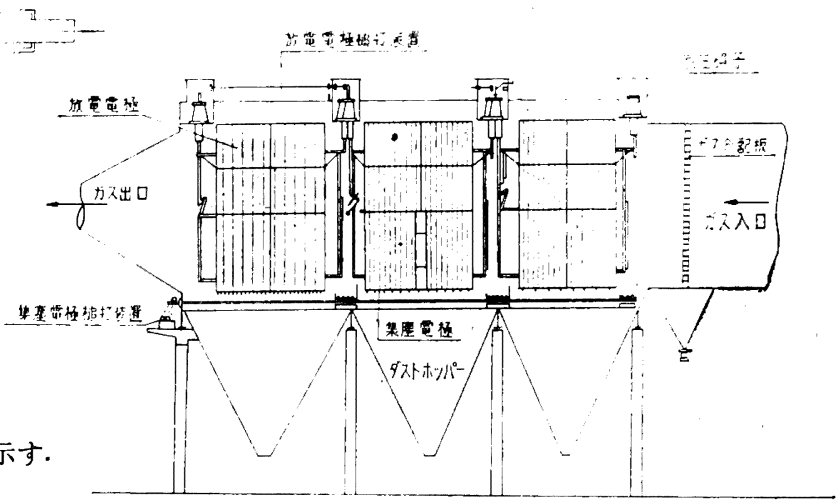

図4.18 乾式電気集塵器

さらに翼車により䚌拌し清浄するもので, 容量は100,000 $\mathrm{m}^{3} / \mathrm{h}$ のものまで製作されている. しかしこの形式のも のは電気集麼器に較べて電力使用量が大であり, 清浄度 
も劣るので最近は余り採用されなくなつた。

\section{(5) 電気集瀶器}

現在, 集壁装置として最も効率のよいのは電気集㖸器 である、この種の集栕器を大別すると乾式電気集闎器と 湿式電気集糜器となる．電気集棌器の特街は放電極之集 鹰極との間に高電圧を加之，その間を通過する物質をイ オン化して集魔極に付着させ，この付着ガス灰を水また は打潫により脱落させて捕集するものである. 図4.16に ルルギー式湿式電気集麼器, 眓4.17にウェスタン式湿式 電気集塺器, および図 $4 \cdot 18$ 亿乾式電気集塺器を示す.
的からみれば最良の方法とはいいがたい、高炉ガス，ま たはコークス炬ガスによる乾燥前に薪による乾燥を行な うこともあるが，作業を簡略化するため廃止する場合も ある・乾燥工程の後期または落熱期においては本バーナ 一から然焼して煙道に排気する方法に切替兄られる。乾 燥, 萻熱過程における加熱速度の調節は排気部に熱電対 を挿入し排気温度を検出して計画に基づき加熱作業を行 なら。また排気中の水分測定は乾燥進行状態を感知する ため重要な作業である. 熱風炉の乾燥蓄熱期間は通常20 〜30日で特に初期においては徐々に型熱することが仠要 である. 四 $4 \cdot 19$ に加熱面積 $30,000 \mathrm{~m}^{2}$ の熱風炉の乾燥

\section{$4 \cdot 6$ 火入, 吹卸}

\subsection{1 高炉ならびに熱風炉の乾燥}

高炉ならびに熱風炉の築造が完了する 之, 各炉体煉瓦積の乾燥を開始する. 通常, 熱風炉は乾燥作業に引続き蓄熱を行なう。 蓄熱は熱風炉の排気温度に注意しながら熱 風妒内温度分布状況を操業期の状態に漸次 移行するのであるが，このとき高炉の熱風 乾燥を行ならと, 熱風炉の切替操作をとも なうので蓄熱が割合円滑にできる・乾燥作 業は柬瓦積内部の水分を完全に除去するこ とであるから，昇温は漸進的に行なつて煉 瓦および目地の亀裂を防止しなければなら ない.このため熱源附近が局部加熱され易

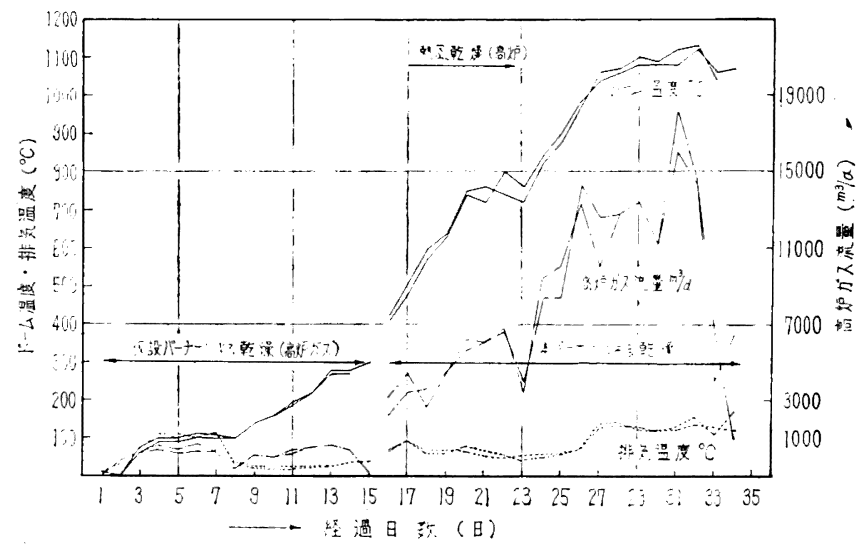

图 4 . 19 熱風炉乾燥・蓄熱实績例

い直火方式はさけ，ガス雾用気による間接加熱方式が適 切な方法である。

\section{（1）熱風炉の葫燥，蓄熱}

熱風炉の乾燥は稼働中の高炉またはコークス炉の有無 により乾燥方法が異なつてくる. 熱風炉の乾燥には最初 然焼室,および蓄熱室下部より加熱して,ドームのマン ホールより排気する方法と，ドームのマンホールを閉め 然焼室下部より加熱して煙道から排気する方法がある. 高炉ガスまたはコークス炉ガスが利用できないときは 熱風炉の然焼口前, 煙道口前に乾燥用前炬を築造し, 燃 料として薪, 石炭, コークス，あるいは液体然料を使用 する・高炉ガス，またはコークス炉ガスの使用が可能な 場合は, 最初からこれらの燃料ガスを使用し，仮設の小 容量のバーナーで乾燥を始める，高炬ガスを最初から使 用する場合は，バーナー部の雲囲気温度が低いため火炎 が消隇することがある：このため、コークス炉ガスの点 火用バーナーを併用するここが安全である・またコーク ス炬ガスを燃料とする乾燥は排気温度が低い間, 水蒸気 が凝縮して煉瓦表面に水滴となつて附着するため乾燥目
蕃熱实績を示す.

（2）高炉乾燥

稼働中の高灯およびこークス炉がなく，また高炉乾燥 工程に熱風炉蓄熱が遅れた場合，出銑口，出涬口前に乾 燥用前灯を築造して薪，石炭，およびュークスなどを燃 料として乾燥することがあるが，近年に打いては，この 種の乾燥方法は注とんど行なわれていない、ニークス炉 ガスによる乾燥は熱風乾燥前に行なわれることもある が，最近は熱風のみで乾燥を行なう例が多い，熱風乾燥 を行なうときは, 通常風量を略々一定にして冷風から始 め, 徐々に熱風温度を $600^{\circ} \mathrm{C}$ 程度まで上界し, 炉頂ガス 温度が約 $300^{\circ} \mathrm{C}$ になるまで行なうのが普通である。炬底 にカーボン煉瓦を使用するときは，シャモット質煉瓦で 保護するまた熱風が炉壁に汾つて上昇するように，炉 内に鉄板製の乾燥棚を設置することもあり，その場合吹 込羽口には炬壁に沿つて熱風が旋回して上界するように 先端を一定角度に曲げた尊管を取付ける. 通常, 高炬の 乾燥期間には15〜30日を要する. そして乾燥終了後, 埧 充のため $1 \sim 2$ 日の冷却期が必要である. 熱風乾燥がで 
きないときは，薪，またはコークス炬ガスで乾燥を始め る. 図4-20k内容積 $1,279 \mathrm{~m}^{3}$ の高炉の乾燥実績を示す.

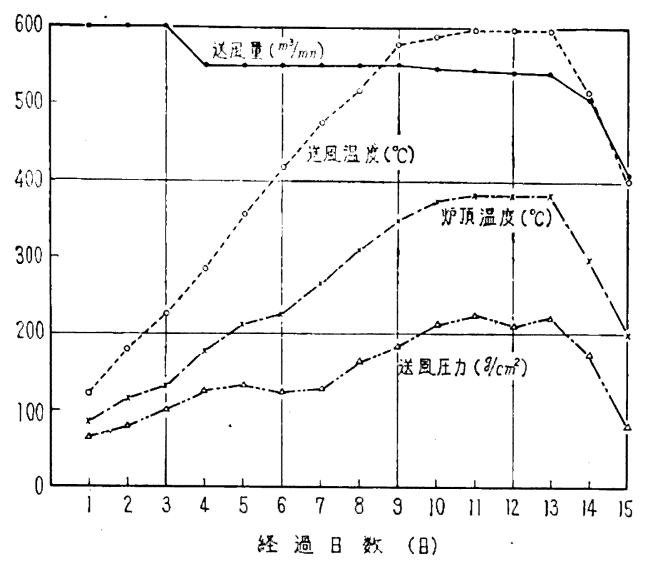

図4-20 高炉乾燥実績

\section{$4 \cdot 6 \cdot 2$ 填 充}

(1) 枕木媜充

高炉㶱瓦積みの乾燥が終ると，炬内に装入物の媜充を 開始する．填充においては送風羽口部から枕木を炉内に 搬入し，炬床部に積む。枕木積は下部は粗に上部では密 になるよ5にし，出銑口，出涬口前部にはガス吹出通路 として空間を作るのが普通である. 最近の傾向として， 枕木の積み方を種々改善し，なるべく视木数量を少なく するようになつた・一般に着火を容易にするため枕木皘 上部および羽口前面に乾燥した木炭, 薪を挿入する.

\section{（2）高炉原料の填充}

枕木塤充が完了すると，巻上機怙よび炉頂装入装置な どの試運転をかねて炉頂から原料を装入する，媜充物と しては,コークス, 焼結鉱, 整粒鉱, 石灰石, 高炉涬, 珪石，および屑鉄などである，最近では還元および造涬 性の良好な焼結鉱の使用割合が增加する傾向にあり，全 自溶性焼結鉣で吹入れ操業を行なつた高炉もある。また 近年は，コークスペース，炉頂部に括ける鉣石コークス の比, および造滓量について検討し, 立上り操業速度を 速くする方向に改善されている. 通常, 装入物の填充に おいては炉内を9〜13 層に分割して各段について計算仮 定を設け，これに基ついて原料を装入する．過去の高炉 吹入実績から填充計算仮定を要約して次に示す.

a. 吹製銑鉄成分（初湯）

$\begin{array}{lcccc}\mathrm{Fe} & \mathrm{C} & \mathrm{Si} & \mathrm{Mn} & \mathrm{S}+\mathrm{P}+\mathrm{Cu}+\cdots \\ 90 \sim 91 \% & 3.5 \% & 3.0 \sim 4.0 \% & 0.8 \% & 0.5 \% \\ \text { b. 還 元 率 } & & & \end{array}$

Fe : 99.0 99.5\% Mn : 65 70\%

c、鉣石/コークス

最上段： $1 \cdot 3 \sim 1 \cdot 6$ (最近では最上段の鉱石/コーク スは増大の傾向にある.)

4 段目: $0.07 \sim 0.09$

2〜3段目: コークス, 石灰石, 鉣涬のみ装入

d. 造 㳯量

最上段: $0.5 \sim 0.7 \mathrm{t} / \mathrm{t} \cdot$ pig これを基準として, 100 とし

6〜7段：105〜110を最大鉱涬比としてそれより下段 表 4.5 填 充 実 績

\begin{tabular}{|c|c|c|c|c|c|c|c|c|c|c|c|c|c|c|c|c|c|c|}
\hline \multirow{4}{*}{$\begin{array}{l}\text { 段 } \\
\text { 数 }\end{array}$} & \multicolumn{2}{|c|}{$\begin{array}{c}\text { 高さ (m) } \\
\text { (予定) }\end{array}$} & \multirow{4}{*}{$\begin{array}{c}\text { 内 } \\
\text { 容 } \\
\text { 積 } \\
\left(\mathrm{m}^{3}\right) \\
\end{array}$} & \multicolumn{2}{|r|}{ 装 } & \multicolumn{5}{|c|}{$\mathrm{kg}$ (1 回当り) } & \multirow{2}{*}{\multicolumn{2}{|c|}{$\begin{array}{l}\text { 各段における } \\
\text { 生成量 }(\mathrm{kg} / \text { 回 }\end{array}$}} & \multirow{2}{*}{\multicolumn{2}{|c|}{\begin{tabular}{|c} 
装入 \\
回数 \\
(予定) \\
\end{tabular}}} & \multicolumn{2}{|c|}{ 害 } & \multicolumn{2}{|r|}{ 表責 } \\
\hline & $\begin{array}{l}\pi \\
\\
y\end{array}$ & & & \multirow{3}{*}{$\begin{array}{l}ב \\
1 \\
n \\
x\end{array}$} & \multirow{3}{*}{$\begin{array}{l}\text { 鉄 } \\
\text { 鋳 } \\
\text { 物 } \\
\text { 焼 } \\
\text { 結 }\end{array}$} & \multirow{3}{*}{$\begin{array}{l}\text { 鉱 } \\
\text { 金 } \\
\text { 谷 }\end{array}$} & 吕 & \multirow{3}{*}{ 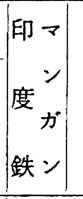 } & \multirow{3}{*}{$\begin{array}{l}\text { : } \\
\text { ラ } \\
\text { ス }\end{array}$} & \multirow{3}{*}{$\begin{array}{l}\text { 石 } \\
\text { 灰 } \\
\text { 石 }\end{array}$} & & & & & \multirow{2}{*}{\multicolumn{2}{|c|}{$\begin{array}{l}\text { ストック } \\
\text { ラインよ } \\
\text { ク各段上 } \\
\text { 端まで }\end{array}$}} & \multirow{2}{*}{\multicolumn{2}{|c|}{$\begin{array}{l}\text { 装入 } \\
\text { 回数 }\end{array}$}} \\
\hline & 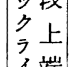 & & & & & & \multirow[b]{2}{*}{ 計 } & & & & \multirow{2}{*}{$\begin{array}{l}\text { 銑 } \\
\text { 鉄 }\end{array}$} & \multirow{2}{*}{ 䚗 } & \multirow{2}{*}{$\begin{array}{l}\text { 各 } \\
\text { 段 }\end{array}$} & \multirow{2}{*}{\begin{tabular}{|l} 
累 \\
計
\end{tabular}} & & & & \\
\hline & 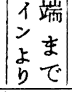 & & & & & & & & & & & & & & 側 & 品 & 各 & 句 \\
\hline & $1 \cdot 0$ & $3 \cdot 7$ & 1048 & & 12,000 & 0,000 & 0 & 240 & 500 & - & | & (2) & 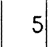 & 55 & $1 \cdot 2$ & 11 & 4 & 0 \\
\hline & $4 \cdot 7$ & $3 \cdot 8$ & $177 \cdot 2$ & 10,000 & 9,600 & 2,400 & 12,000 & 190 & 1,150 & 1,200 & 7,274 & 4,536 & 6 & 50 & $7 \cdot 0$ & $7 \cdot 0$ & 6 & 51 \\
\hline & $8 \cdot 5$ & $2 \cdot 9$ & $167 \cdot 3$ & 10,000 & 7,200 & 1,800 & 9,000 & 140 & 1,750 & 1,100 & 5,474 & 4 , & 6 & 40 & $9 \cdot 9$ & $10 \cdot 1$ & 6 & 45 \\
\hline & $11 \cdot 4$ & $2 \cdot 7$ & $160 \cdot 0$ & 10,000 & 5,000 & 1,300 & 6,300 & 100 & 2,500 & 750 & 3,852 & 4,536 & 6 & 38 & $12 \cdot 6$ & $12 \cdot 9$ & 6 & 39 \\
\hline & $14^{\cdot} 1$ & $2 \cdot 3$ & $151 \cdot 3$ & 10,000 & 2,900 & 700 & 3,600 & 60 & 3,100 & 600 & 2,239 & 4,536 & 6 & 32 & $14 \cdot 7$ & $15 \cdot 0$ & 0 & 33 \\
\hline & $16 \cdot 4$ & $1 \cdot 8$ & $140 \cdot 3$ & 10,000 & 600 & 100 & 700 & 10 & 2,9 & 550 & 501 & 3,856 & 6 & 26 & $16 \cdot 5$ & $17 \cdot 2$ & 0 & 27 \\
\hline & $18 \cdot 2$ & $3 \cdot 0$ & $220 \cdot 5$ & 10,000 & & & & & 2,250 & 550 & 78 & 3,175 & 10 & 20 & $18 \cdot 2$ & $18 \cdot 3$ & 11 & 21 \\
\hline & $21 \cdot 2$ & $3 \cdot 0$ & $212 \cdot 4$ & 10 & & & & & 1,400 & 700 & 78 & 2,495 & 10 & & $21 \cdot 1$ & $21 \cdot 3$ & 10 & \\
\hline & $24 \cdot 2$ & $4 \cdot 0$ & $286^{\circ} 0$ & $\begin{array}{r}\text { 枕木 } \\
\mathbf{t} \\
550\end{array}$ & $\begin{array}{c}\mathbf{t} \\
211 \cdot 8\end{array}$ & $\begin{array}{c}t \\
52 \cdot 8\end{array}$ & & $\begin{array}{c}t \\
4 \cdot 2\end{array}$ & $\mathrm{t}$ & $\tau$ & $\mathrm{t}$ & $l$ & & & 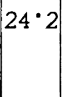 & $\cdot 2$ & & \\
\hline
\end{tabular}


になるにしたがい低くし

2 段：50〜60で最低比とする．ただし，近年造㳯

量を低下するため最上段〜 6段までは同一

造涬量とするような傾向になつている.

e. 鈗㳯塩基度, $\mathrm{CaO} / \mathrm{SiO}_{2}$

最上段: $1 \cdot 10$ 2 3段: 0.95

f. 王縮 率

最上段：5\%および2段目：15\%とする場合，また

最上段：10\%扣よび2 段目：20\%とする場合などが ある。

鉱石埧充の一例を表 $4 \cdot 5$ に示す.

\section{$4 \cdot 6 \cdot 3$ 吹}

入

吹入に先立つて, 羽ロに一重あるいは二重に羽ロリン グを挿入する. 羽ロリングは操業条件により異なるが， 例えば鋳鉄製，または銅製のリング $(110 〜 120 \mathrm{~mm} \phi)$ と 煉瓦製，またはキャスタブル製のリング (80〜90 mm を二重に挿入している．点火は送風羽口から行ない，着 火を容易にするため $500 \sim 600^{\circ} \mathrm{C}$ 程度の熱風で送風を開 始する．吹入後，炉底部加熱のため出銑口，出涬口を開 ロしておき，炉内ガスを噴出させて点火する，送風開始 後10〜15時間経過すると, 溶滓が流出し始める. 出滓口 は自然閉塞を待つ場合もあるが，出銑口は初出銑作業を

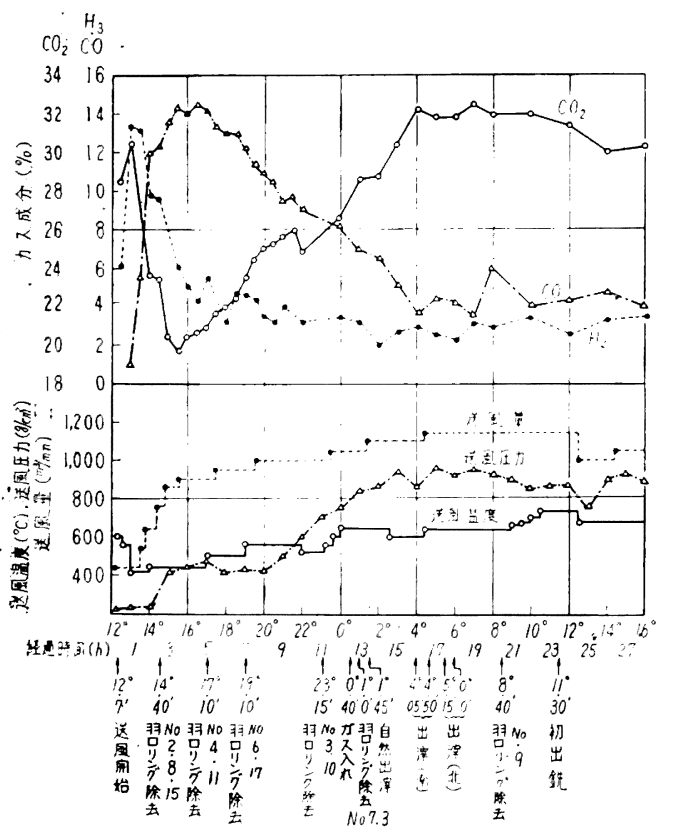

容易にするためマッドで閉塞する．吹入後23〜25時間で 初出銑を行な5.羽ロリングは送風量の增加とともに漸 次取除いていく.ガス連絡時刻は既存の高炉設備の有無 その他の状沉により異なるが，一般にガス爆発の危険性 を考虑して，炉㑯ガスの組成を確認しながら行なう．装 入開始と共に装入線を所定の位置まで上升させ, 計画に したがつて鉣石を增していく.図 $4 \cdot 21$ に内容積 $1,243 \mathrm{~m}^{3}$ の高炉の吹入操業实績を示す.

\subsection{4 吹入後の操業}

初湯は高 $\mathrm{Si}$ 銑となり，普通䄪 1 力月程度は鋳物銑を吹 製するが，製鋼銑の必要性に応じて約 1 週間程度で鋳物 銑から製鋼銑に銑種を変更する場合もある，最近，放射 性同位元素 $\left(\mathrm{Co}^{60}\right)$ を炬壁に埋込み，炬壁煉瓦侵食状態 を測定する高炉が多くなつた．富士鉒石第 1 高炉の朝顔 部は，吹入後約1 力月でほとんど損耗し，住金和歌山第 1 高炉の朝顔部は50～70日経過して内壁より $300 \mathrm{~mm} の$ 位置まで侵食された。このよ5に吹入後, 短期間に朝顔 部周辺の炉壁煉瓦は侵食されることも多いよ5である. 吹入後は銑鉄生産計画に基づき, 逐次增風して通常操業 条件まで移行するのであるが，近年装入原料の事前処理 の強化により, 過去の高灯に比較して操業速度を早く上 界させることが可能となり，また吹入後の炉沉不調はほ とんどみられなくなつた。

\section{$4 \cdot 6 \cdot 5$ 高炉の寿命}

高炉本体の寿命は, シャフト下部, 朝顔部, 炉休部, および炉底煉瓦皘の物理的化学的の損耗により決定され る.したがつて近年, 炬命延長の対策として高炉は次の ように改良された。

（1）鉄帯式より鉄皮式への改造.

（2）烜瓦品質の向上，特に炉床および朝顔部にカーボ ン煉瓦の使用.

（3）炉体冷却の強化など.

この他, 高炉操業条件を改善し, 安定した操業を継続 することは，炉命延長に非常な効果を与えるものであ る. 高炉原料の事前処理はこの目的に対しても極めて有 利な結果をもたらしたものと考えられる. しかし，高炣 吹卸は単に高炉本体の寿命によつてのみ決定されるもの でなく，その他の経済的な理由などにより行なわれる場 合も多い. 表 4.6 に過去数年間に吹卸された高炉の総出 銑量ならびに炉令を示す.

图4.21 高炬吹入操業実績（神鋼- 神戸） 
表 4.6 高炉炉令ならびに総出銑量の実績

\begin{tabular}{|c|c|c|c|c|c|c|c|c|c|c|c|}
\hline \multicolumn{2}{|l|}{ 高 } & 妒 & \multirow{2}{*}{$\frac{\text { 名 }}{\text { No. } 4}$} & \multicolumn{2}{|c|}{ 吹入年月日 } & \multicolumn{2}{|c|}{ 吹卸年月 日 } & \multirow[t]{2}{*}{ 妒 } & \multirow{2}{*}{$\frac{\text { 命 }}{\text { (年月 }}$} & \multirow{2}{*}{$\frac{\text { 総出 銑 量 }}{\left(\begin{array}{c}\left(\times 10^{3} \mathrm{t}\right) \\
1,560\end{array}\right.}$} & \multirow{2}{*}{ 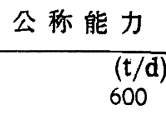 } \\
\hline 鋼 管 & 管 川 & 畸 & & $\mathrm{S}$ & $24^{\cdot} 6^{\cdot 15}$ & $\mathrm{~S}$ & $31^{\cdot} 6^{\cdot} 1$ & & & & \\
\hline 鋼 管 & 㡙 鶴 & 兒 & No. 2 & $\mathrm{~S}$ & $26^{\cdot} 1 \cdot 27$ & S & $31 \cdot 12 \cdot 10$ & & $5 \cdot 11$ & 739 & 300 \\
\hline 住 金 & 金 小 & 倉 & No. 2 & $S$ & $26^{\cdot} 1 \cdot 31$ & $S$ & $32 \cdot 4 \cdot 30$ & & $6 \cdot 3$ & 812 & 350 \\
\hline 八 幡 & 番 洞 & 岡 & No. 3 & $\mathrm{~S}$ & $26^{\cdot} \cdot 3 \cdot 10$ & $\mathrm{~S}$ & $30 \cdot 7 \cdot 30$ & & $4 \cdot 5$ & 1,477 & 1,000 \\
\hline 富 士 & 士 室 & 蘭 & No. 2 & $\mathrm{~S}$ & $26^{\circ} 10^{\circ} 1$ & $\mathrm{~S}$ & $32 \cdot 6 \cdot 30$ & & $5 \cdot 9$ & 1,377 & 700 \\
\hline 富 士 & 士 爻 & 石 & No. 1 & $\mathrm{~S}$ & $27^{\cdot} 8 \cdot 28$ & $\mathrm{~S}$ & $33 \cdot 8 \cdot 15$ & & $6 \cdot 0$ & 1,622 & 700 \\
\hline 八 幡 & 潘 洞 & 岡． & No. 4 & $\mathrm{~S}$ & $27^{\circ} 12^{\bullet} 1$ & $\mathrm{~S}$ & $36 \cdot 6 \cdot 30$ & & $8 \cdot 7$ & 3,630 & 1,000 \\
\hline 鋼 管 & 管 川 & 崎 & No. 5 & $\mathrm{~S}$ & $27 \cdot 12 \cdot 15$ & $S$ & $35^{\cdot} 2 \cdot 1$ & & $7 \cdot 1$ & 1,927 & 600 \\
\hline 富 士 & 士広 & 畑 & No. 1 & $\mathrm{~S}$ & $27 \cdot 12 \cdot 25$ & $S$ & $32^{\circ} 4^{\cdot} 1$ & & $4 \cdot 3$ & 1,491 & 1,000 \\
\hline 中 & & 山 & No. 2 & $\mathrm{~S}$ & $28 \cdot 83 \cdot 18$ & $\mathrm{~S}$ & $34^{\circ} 4^{\cdot} 2$ & & $6 \cdot 1$ & 1,153 & 450 \\
\hline 尼 & & 鉄 & No. 1 & $\mathrm{~S}$ & $28^{\circ} 4^{\bullet} 1$ & $\mathrm{~S}$ & $34 \cdot 12^{\cdot} 1$ & & $6 \cdot 8$ & 1,045 & 400 \\
\hline 富 士 & 上，室 & 闌 & No. 1 & $\mathrm{~S}$ & $28 \cdot 5 \cdot 26$ & $\mathrm{~S}$ & $34^{\cdot} 8^{\cdot} 4$ & & $6 \cdot 2$ & 1,675 & 700 \\
\hline 川鉄 & 失 千 & 葉 & No. 1 & $\mathrm{~S}$ & $28 \cdot 6 \cdot 17$ & $S$ & $36 \cdot 8 \cdot 17$ & & $8 \cdot 2$ & 2,403 & 600 \\
\hline 富 士 & 上釙 & 石 & No. 2 & $\mathrm{~S}$ & $29^{\circ} 12^{\bullet} 1$ & $\mathrm{~S}$ & $36^{\cdot} 6 \cdot 30$ & & $6 \cdot 7$ & 2,002 & 700 \\
\hline
\end{tabular}

\subsection{6 吹止操業}

従来の吹止要領は吹止後の炉内装入物の取出作業を容 易にするため,コークス割合を増加した軽装入操業と し，吹止直前に装入線を大巾に下げて吹止する場合が多 い上ラであつたしかしこの作業方法は炉内空間を拡 大してガス容積を増し, また炉頂ガス温度が上界し, 炉 頂ガス爆発の場合に被害を增大する懸念があつた。この 対策として近年の吹止操業では装入線を変更せずに吹止 することが多くなつた，吹止前は，溶銑，涬の流動性に 悪影部を与えないよ5装入物の化学的組成について考庶

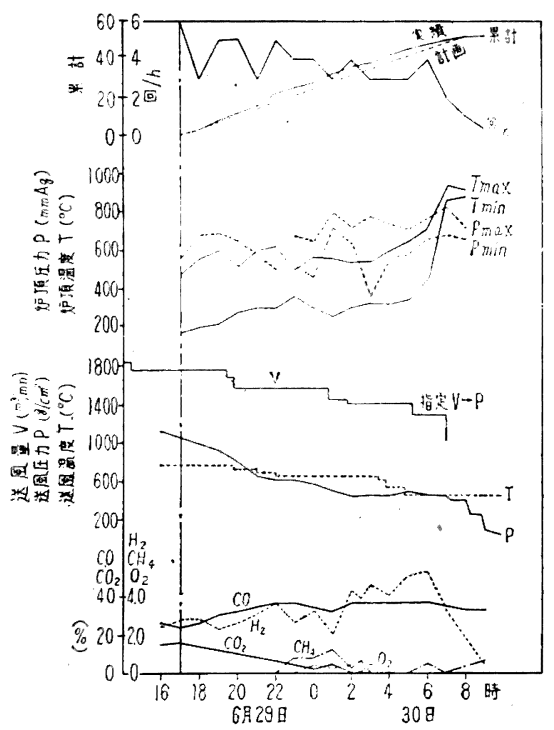

図 $4 \cdot 22$ 高炉吹卸操業実績例（八幡・洞岡）
せねばならない，吹止のため軽装入物に切替えた後，送 風量ならびに送風温度を漸次低下させる，この場合，軽 装入物のため帄内通気抵抗が極めて低く, 炬頂ガス温度 は.上䄯し易い，一般に炉頂ガス温度の上昇に対しては装 入直前に装入物に注水する，吹止後，直ちに炬底に臨時 出銑口を開孔し，完全に溶銑と溶㳯を取出す.その後, 炉頂から注水して内容物を冷却し羽口附近から掻出す. 図 4.22にS36年6月30日に吹止された内容積 $1,183 \mathrm{~m}^{3}$ の高炉の吹卸操業実績を示す．また図4・23に同高炉吹卸 後の炉壁侵食状況を示す.

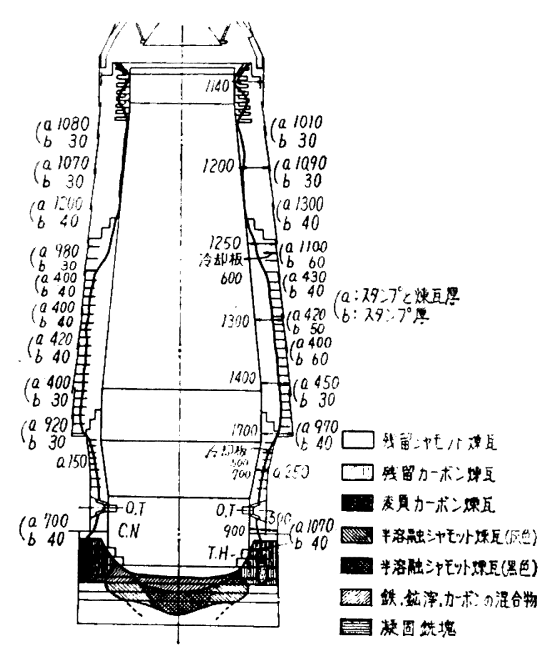

図 $4 \cdot 23$ 吹卸後の炉壁侵食状況の一例（八幡・洞岡） 
図4・23から明らかであるが，最近の炉壁侵食状態の傾 向としては, 先ず原料処理が改善されたため, 灯胸部の 附着層はほとんど見られなくなつた。それと同時に，朝 顔、炬腹, 炬胸下部ライニングの損伤が著しくなつたよ 5に考えられる.過去の高炬に打いては湯溜部ライング
の損䈷によりしばしば吹止されることが多かつたが，近 年に批いては, 炬底, 灯床, および朝顔ライニングにカ 一ボン䗲瓦を使用したため，この部分の損耗は少なくな つている. 